\title{
Drought Stress Amelioration in Maize (Zea mays L.) by Inoculation of Bacillus spp. Strains under Sterile Soil Conditions
}

\author{
Muhammad Azeem ${ }^{1,+}{ }^{\mathbb{D}}$, Muhammad Zulqurnain Haider ${ }^{2} \mathbb{D}$, Sadia Javed ${ }^{1} * \mathbb{D}$, Muhammad Hamzah Saleem $^{3} \mathbb{D}$ \\ and Aishah Alatawi ${ }^{4}$ \\ 1 Department of Biochemistry, Government College University, Faisalabad 38000, Pakistan; \\ muhammadazeem134@gmail.com \\ 2 Department of Botany, Government College University, Faisalabad 38000, Pakistan; drmzhaider@gcuf.edu.pk \\ 3 College of Plant Science and Technology, Huazhong Agricultural University, Wuhan 430070, China; \\ saleemhamza312@webmail.hzau.edu.cn \\ 4 Biology Department, Faculty of Science, Tabuk University, Tabuk 71421, Saudi Arabia; \\ Amm.alatawi@ut.edu.sa \\ * Correspondence: sadiajaved@gcuf.edu.pk \\ $+\quad$ This research work is the part of M.Phil. thesis of Muhammad Azeem.
}

check for updates

Citation: Azeem, M.; Haider, M.Z.; Javed, S.; Saleem, M.H.; Alatawi, A. Drought Stress Amelioration in Maize (Zea mays L.) by Inoculation of Bacillus spp. Strains under Sterile Soil Conditions. Agriculture 2022, 12, 50. https://doi.org/10.3390/ agriculture 12010050

Academic Editors: Daniele Del Buono, Primo Proietti and Luca Regni

Received: 16 November 2021 Accepted: 21 December 2021 Published: 1 January 2022

Publisher's Note: MDPI stays neutral with regard to jurisdictional claims in published maps and institutional affiliations.

Copyright: () 2022 by the authors Licensee MDPI, Basel, Switzerland. This article is an open access article distributed under the terms and conditions of the Creative Commons Attribution (CC BY) license (https:// creativecommons.org/licenses/by/ $4.0 /)$.

\begin{abstract}
The aim of the present study was to promote plant growth characteristics including mineral uptake and various phytohormone production by indigenously isolated Bacillus spp. strains. Plants subjected to normal and water stress conditions were collected after 21 days to measure physiological parameters, photosynthetic pigment estimation, biochemical attributes, lipid peroxidation and antioxidant enzyme response modulation. Our results correlated with drought stress amelioration with the inoculation of Bacillus spp. strains BEB1, BEB2, BEB3 and BEB4 under sterile soil condition. Inoculated plants of both maize cultivars showed increases in fresh (56.12\%) and dry (103.5\%) biomass, plant length $(42.48 \%)$, photosynthetic pigments $(32.76 \%)$, and biochemical attributes with enhanced nutrient uptake. The overall maize antioxidant response to bacterial inoculation lowered the malonaldehyde level (59.14\%), generation of hydrogen peroxide (45.75\%) and accumulation of flavonoid contents in both control and water stress condition. Activity of antioxidant enzymes, catalase $(62.96 \%)$, peroxidase $(23.46 \%)$, ascorbate peroxidase $(24.44 \%)$, and superoxide dismutase $(55.69 \%)$ were also decreased with the application of bacterial treatment. Stress amelioration is dependent on a specific plant-strain interaction evident in the differences in the evaluated biochemical attributes, lipid peroxidation and antioxidant responses. Such bacteria could be used for enhancing the crop productivity and plant protection under biotic and abiotic stresses for sustainable agriculture.
\end{abstract}

Keywords: plant growth-promoting bacteria; biological control; abiotic stress; drought tolerance; antioxidants enzymes; plant microbiome

\section{Introduction}

Drought is the major problem for corn plants and has become a source of dietary threat to food security and human health [1]. Drought stress is directly proportional to climate change. Because of the catastrophic loss of arable land due to drought stress, meeting the need of an overpopulated globe for food, shelter, and clothing will be a worrisome concern in the future [2,3]. The water deficiencies lead to reducing the overall plant growth by lowering photosynthetic activity, hormone production and membrane stability [4,5]. Lack of water causes the production of reactive oxygen species (ROS) in plants and induces irreversible damage to a metabolic system that ultimately triggers the cell damage [6].

Under water deficit conditions, the ROS including hydroxyl, superoxide, hydrogen peroxide and many other free radicals are very damaging for the normal metabolic pathways of the plants. The excessive presence of ROS in plant leaves causes the chemical 
oxidation of important cellular biomolecules, including proteins, lipids, nucleic acids and chlorophylls, which leads to cell death [7]. The antioxidant system of plant enzymatic or non-enzymatic mechanisms work in coordination to normalize the oxidative stress by neutralizing toxic ROS [2]. Both mechanisms involve the removal of ROS to reduce the oxidative damage to the plant cell [8]. The low molecular weight organic compounds including many sugars, amino acids, proline help the plant cells to normalize the fluid level for balanced cellular metabolic pathways [9].

In Pakistan, maize is one of the top three cereal crops, along with wheat and rice. Total maize production was 7,800,000 tons in 2020. To meet the required food and nutrition for an ever-growing population all over the world, the cereal production needs to be upgraded in drought conditions. In this respect, several approaches and biofertilizers are used to enhance the drought tolerance and promote plant growth $[10,11]$. The current agricultural crop production approaches are costly and non-renewable; for example, improper fertilizer and pesticide inputs may result in the production of greenhouse gases and cause a variety of environmental and human health problems [12]. In this regard, the use of beneficial microbes could be a stress protecting agent for plants and lead to promising solutions for a sustainable and environment-friendly agriculture $[2,13]$.

Beneficial soil microorganisms are being used to boost plant growth and production as part of these efforts. Plant growth-promoting rhizobacteria (PGPR) are beneficial rhizobacteria that can be employed to boost plant growth and productivity [9]. When PGPR is introduced to plant seeds or roots, it has the potential to colonize the entire root system, consuming amino acids and sugars contained in root exudates as a source of food and energy to activate plant growth-promotion activities, resulting in increased plant growth and yield [14]. On various crops, inoculating plants with PGPR can enhance growth by up to 500 percent and yield by up to 57 percent.

Plant growth promoting bacteria eliminate abiotic stress in plants and grasses including by inoculation to their rhizosphere [14]. The PGP bacteria in the rhizosphere promote the nutrient uptakes and modulate the production and metabolism of plant hormones including auxin, abscisic acid, cytokinin, ethylene and gibbereellins $[13,15]$. Bacteria having the ability to produce enzyme 1-aminocyclopropane-1-carboxylate (ACC) deaminase reduce the level of endogenous ethylene in plants to regulate the growth and development [13]. The endophytic bacteria comprising the capability of solubilizing phosphate and fixing nitrogen are considered very efficient biofertilizers for the accessibility of atmospheric inorganic elements to the plant [16]. Numerous microbes have been described that solubilize the phosphorus by converting it from an insoluble to soluble form through acidification, chelation, and redox reactions [2].

On the many taxonomic groups of PGPR, numerous reviews and research papers have been published $[2,17]$. Indigenous bacillus strains from the textile effluents are the focus of this study because bacillus PGPR gets a lot of attention around antioxidant stress relief. Because of their ability to withstand severe environments and mitigate plant drought stress, these strains may lead to the development of biotechnologies for plant growth promotion in arid and semiarid regions. Accordingly, the purpose of this study was to analyze effect of inoculation of four textile effluent isolated Bacillus spp. strains on the growth, physiology, biochemical attributes, lipid peroxidation and antioxidant enzyme response modulation of a drought-sensitive plant like maize under water deficit.

\section{Materials and Methods}

\subsection{Isolation and Characterization of Bacterial Microflora}

The textile industrial effluent samples were collected in $500 \mathrm{~mL}$ sterile bottles from Kamal textile (Pvt) Jaranwala Road, Faisalabad, Punjab, Pakistan (Google map location: $31.469006616012493,73.30483972821574)$. Serially diluted $\left(10^{-1}, 10^{-2}, 10^{-3}, 10^{-4}\right.$ and $\left.10^{-5}\right)$ effluent samples applied for microbial growth by a standard spread plate method [18] on nutrient agar medium and incubated at $37{ }^{\circ} \mathrm{C}$ for $24 \mathrm{~h}$. The bacterial cell shape and color were examined under the microscope at $100 \times$ using oil emersion after staining 
with a gram staining method. A single colony mixed in a drop of $3 \% \mathrm{H}_{2} \mathrm{O}_{2}(v / v)$ on a glass slide and observed for effervescence of $\mathrm{O}_{2}$ bubbles [19]. A starch hydrolysis test was performed to check the ability of microbes to produce amylase enzyme using Lugol's solution $\left(\mathrm{KI}\right.$ and $\left.\mathrm{I}_{2}\right)$ [20]. Casein agar plates were utilized to check the production of protease enzymes by isolates [21]. The ability of bacterial isolates to produce exopolysaccharides was checked using LB broth, after incubation of 2 days at $37 \pm 2{ }^{\circ} \mathrm{C}$ cultures were centrifuged, supernatant was mixed with $100 \%$ chilled ethanol in equal volume and precipitation was observed [22].

\subsection{Taxonomic Identification and Phylogenetic Analysis}

Genomic DNA was extracted from pure isolate by a GF-1 extraction kit for bacterial DNA. The 16S rRNA were replicated utilizing a universal primer: 27F (AGAGTTTGATCCTGGCTCAG) and 1492R (TACGGYTACCTTGTTACGACTT). The PCR amplification was performed according to DNA Taq polymerase protocol [23]. The products of PCR reaction were analyzed on agarose gel to ensure successful 16S rRNA gene amplification. DNA sequencing was done at MACROGEN, the sequencing company, Seoul, Korea working with ABI 3100, the automated sequencer with Big Dye Terminator Kit v. 3.1 with Sanger's dideoxy method using the same set of primers. The phylogeny was described by BLASTn analysis and by constructing the phylogenetic tree with the type species. The phylogenetic tree was built by utilizing the neighbor-joining (NJ) technique [24] following multiple sequence alignment results of ClustalW in the MEGA X [25] software package. The clustering constancy of the tree was estimated by a bootstrap study [26] of 100 data sets.

\subsection{In Vitro PGP Traits}

Peptone water broth medium was incubated with an isolated strain for $72 \mathrm{~h}$ at $37 \pm 2{ }^{\circ} \mathrm{C}$ and $120 \mathrm{rpm}$ in a shaking incubator. After 48 and $72 \mathrm{~h}$, the amount of ammonia produced was estimated by Nessler's reagent [27].

Salkowski reagent method [28] was used for IAA quantification of bacterial isolates in LB medium containing $1 \mathrm{~g} / \mathrm{L}$ tryptophan for 3 days in both normal and water stress conditions. Indole acetic acid (IAA) was used for a standard curve.

Estimation of nitrogen fixation was done to check the ability of bacterial isolates to covert the nitrogen gas from atmosphere into nitrogen form that is usable by plants. Nitrogen free malate medium was inoculated with bacteria and incubated for 7 days at $37 \pm 2{ }^{\circ} \mathrm{C}$ and $120 \mathrm{rpm}$ in a shaking incubator, and plates were incubated for 7 days at $37 \pm 2{ }^{\circ} \mathrm{C}$ in an incubator to check the efficiency of bacteria to fix nitrogen [29].

The inorganic phosphate solubilizing activity of bacterial isolates was observed by using NBRIP agar medium [30]. Freshly grown pure colony of isolates was spotted on the NBRIP agar plate and allowed to incubate it for 7 days at $37 \pm 2{ }^{\circ} \mathrm{C}$ and observed daily for zone formation. Formation of a clear halo zone around the bacterial colony indicates the phosphate solubilizing activity. The potential of bacterial isolate to solubilize inorganic phosphate was estimated by calculating the solubilization index (SI) using formula: Solubilization Index $(\mathrm{SI})=$ Colony diameter $(\mathrm{mm})+$ Zone diameter $(\mathrm{mm}) /$ Colony diameter $(\mathrm{mm})[31]$.

\subsection{In Vitro Drought Tolerance}

The effects of drought on the growth of isolates were studied using polyethylene glycol MW 6000 (PEG) at different concentrations ranging from 0 to $25 \%$. The isolates were inoculated in LB broth containing different concentrations of PEG (5\%, 10\%, 15\%, 20\%, and $25 \%$ ) and incubated at $120 \mathrm{rpm}$ and $37^{\circ} \mathrm{C}$ for days. The bacterial growth was measured spectrophotometrically at OD $600 \mathrm{~nm}$ [32]. 


\subsection{Pod Experiment}

Inoculum suspension for seed treatment was prepared by mixing a single colony of a bacterial strain into the nutrient agar broth medium and incubating the culture for 24 to $48 \mathrm{~h}$ at $37^{\circ} \mathrm{C}$. The bacterial cells were washed three times with sterile distilled water by vortex mixing and centrifugation at $6000 \mathrm{rpm}$ for $5 \mathrm{~min}$ using a sterile $15 \mathrm{~mL}$ centrifuge falcon tube. Following vertexing, a spectrophotometer was used to measure the absorbance $(600 \mathrm{~nm})$ of the cell suspension, which was then diluted to $10^{8} \mathrm{cfu} / \mathrm{mL}$ with sterile PB. The surface-sterilized seeds were placed in bacterial suspension on continuous shaking at $120 \mathrm{rpm}$ for $8 \mathrm{~h}$ to insure colonization during seed germination.

Experiment was designed in a completely randomized way with three replicates comprising a total of 60 pots (Bacterial treatments $(5) \times$ water stress $(2) \times$ cultivars $(2) \times$ replicates $(3)=60$ ). Five treatments were used for pot experiments and include (T0) control (sterile distilled water); (T1) Bacillus cereus strain BEB1; (T2) Bacillus cereus strain BEB2; (T3) Bacillus tropicus strain BEB3; (T4) Bacillus thuringiensis strain BEB4. Seeds of two maize (Zea mays L.) cultivars (V1: FH-1046; V2: YH-5427) were collected from the Maize and Millets Research Sub-section, Ayub Agriculture Research Institute, Faisalabad, Pakistan. Soil was collected from the Botanical Garden, Department of Botany, GC university, Faisalabad, Pakistan and autoclaved at $121^{\circ} \mathrm{C}$ for $15 \mathrm{~min}$ before use. The physiochemical properties of the soil used for the experiment are given (Table 1). Ten seeds of corn were sown in $350 \mathrm{~g}$ of soil for each pod. Pots were arranged in a completely randomized design on a bench in a greenhouse where temperatures varied from $24{ }^{\circ} \mathrm{C}$ (night) to $31^{\circ} \mathrm{C}$ (day). The experiment lasted for 21 days during which pots were watered once a day. After germination, the seedlings were thinned to five per pod and maintained in a light growth chamber. The drought stress was maintained by soil water content method, by measuring the weight of dry and watered soil of normal and stress. The normal (non-stress) and drought (stressed) plants were maintained by weighing at 15-18\% and 5-8\% water content in the soil, respectively.

Table 1. Physicochemical soil characteristics used in the plant growth promotion experiment.

\begin{tabular}{|c|c|}
\hline Parameter & Values \\
\hline Texture & Clay loam \\
\hline $\mathrm{pH}$ & 8.6 \\
\hline $\mathrm{EC}\left(\mathrm{dSm}^{-1}\right)$ & 2.93 \\
\hline Sodium adsorption ratio (SAR) $\left(\mathrm{mmol}^{-1}\right)^{2}$ & 6.5 \\
\hline Nitrogen $(\%)$ & 0.014 \\
\hline Phosphorus (ppm) & 3.0 \\
\hline Potassium (ppm) & 40 \\
\hline Organic matter & 0.28 \\
\hline Saturation $(\%)$ & 32 \\
\hline Sand $(\%)$ & 45.5 \\
\hline Silt (\%) & 42.5 \\
\hline Clay $(\%)$ & 12.5 \\
\hline $\mathrm{HCO}_{3}\left(\mathrm{mmol}^{-1}\right)$ & 3.55 \\
\hline $\mathrm{Cl}^{-}\left(\mathrm{mmol}^{-1}\right)$ & 2.34 \\
\hline $\mathrm{SO}_{4}{ }^{2-}\left(\mathrm{mmol}^{-1}\right)$ & 6.67 \\
\hline $\mathrm{Ca}^{2+}+\mathrm{Mg}^{2+}\left(\mathrm{mmol}^{-1}\right)$ & 3.5 \\
\hline $\mathrm{Na}^{+}\left(\mathrm{mmol}^{-1}\right)$ & 3.7 \\
\hline $\mathrm{K}^{+}\left(\mathrm{mmol}^{-1}\right)$ & 0.06 \\
\hline Available $\mathrm{Cu}^{2+}\left(\mathrm{mg} \mathrm{kg}^{-1}\right)$ & 0.35 \\
\hline Available $\mathrm{Zn}^{2+}\left(\mathrm{mg} \mathrm{kg}^{-1}\right)$ & 0.85 \\
\hline
\end{tabular}




\subsection{Plant Physiological Parameters}

After 21 days of growth, plants were harvested and root and shoot fresh weight were measured. Plant roots were washed with distilled water after harvesting. Root and shoot lengths were measured manually using a ruler. Root and shoot dry weight were recorded, which was subsequently oven dried.

\subsection{Photosynthetic Pigment Estimation}

About $0.5 \mathrm{~g}$ of fresh leaf sample from each applied treatment replicate was completely homogenized in about $10 \mathrm{~mL}$ methanol (80\%). Samples were centrifuged at $12,000 \times g$ for 10 min and kept at $4{ }^{\circ} \mathrm{C}$ overnight [33]. Absorbance of extract was measured using a UV visible spectrophotometer at 663, 645 and 480 for the Chlorophyll a, b and total carotenoid contents:

$$
\begin{aligned}
& \text { Chlorophyll a }(\mathrm{mg} / \mathrm{g} \text { F.Wt })=[12.7(\mathrm{OD} 663)-2.69(\mathrm{OD} 645)] \times \mathrm{V} / 1000 \times \mathrm{W} \\
& \text { Chlorophyll b }(\mathrm{mg} / \mathrm{g} \mathrm{F} \cdot \mathrm{Wt})=[22.9(\mathrm{OD} 663)-4.68(\mathrm{OD} 645)] \times \mathrm{V} / 1000 \times \mathrm{W} \\
& \text { Carotenoid }(\mathrm{mg} / \mathrm{g} \mathrm{F} \cdot \mathrm{Wt})=[(\mathrm{OD} 480)-0.114(\mathrm{OD} 663)-0.638(\mathrm{OD} 645)] \times 1000 / 2500
\end{aligned}
$$

\subsection{Plant Biochemical Attributes}

About $0.5 \mathrm{~g}$ of fresh leaf sample from each applied treatment replicate was completely homogenized in about $10 \mathrm{~mL}$ methanol (80\%). Samples were centrifuged at $12,000 \times g$ for $10 \mathrm{~min}$. Flavonoids were assayed by the method of Zhishen [34]. Total soluble sugars were analyzed by Anthrone's reagent method [35]. About $0.1 \mathrm{~mL}$ sample was mixed with $1 \mathrm{~mL}$ Anthrone's reagent. After boiling for $15 \mathrm{~min}$, the mixture could cool to room temperature. Absorbances of all treated samples were measured at $625 \mathrm{~nm}$.

Estimation of total soluble protein was assayed using the Bradford method [36]. About $50 \mu \mathrm{L}$ of sample was mixed with $1 \mathrm{~mL}$ of Bradford reagent, and absorbance was measured at $595 \mathrm{~nm}$. Protein content was calculated by comparing with the BSA standard curve. For ascorbic acid estimation, a fresh leaf sample $(0.5 \mathrm{~g})$ was completely homogenized in $10 \mathrm{~mL}$ of TCA $(6 \%)$. After that, $4 \mathrm{~mL}$ of the extract was mixed with $2 \mathrm{~mL}$ of dinitrophenyl hydrazine, followed by 1 drop of thiourea. After boiling for $15 \mathrm{~min}$, the mixture could cool to room temperature. To the mixture, five milliliters of 80 percent $\mathrm{H}_{2} \mathrm{SO}_{4}$ were added. Following [37], absorbances of all treated samples were measured at $530 \mathrm{~nm}$ and compared to a standard curve drawn using ascorbic acid concentrations ranging from 10 to $100 \mathrm{mg} / \mathrm{L}$.

Velikova's [38] method was used to determine total hydrogen peroxide $\left(\mathrm{H}_{2} \mathrm{O}_{2}\right)$ levels. After filtration, $1.0 \mathrm{~mL}$ supernatant was combined with $0.5 \mathrm{~mL}$ phosphate buffer and $1 \mathrm{~mL}$ of $1 \mathrm{M}$ potassium iodide in a mixture of $0.5 \mathrm{~mL}$ phosphate buffer and $1 \mathrm{~mL}$ of $1 \mathrm{M}$ potassium iodide. The sample mixtures were thoroughly vortexed, and their absorbance was measured using a spectrophotometer at $390 \mathrm{~nm} . \mathrm{H}_{2} \mathrm{O}_{2}$ was calculated using a standard curve created with tannic acid as the reference.

The method of Cakmak [39] was used to determine MDA levels. In a chilled mortar and pestle containing $5 \mathrm{~mL}$ of 1 percent $(w / v)$ TCA, a fresh leaf sample $(0.5 \mathrm{~g})$ was ground. For $10 \mathrm{~min}$, the mixture was centrifuged at 15,000 rpm. About $1 \mathrm{~mL}$ of 0.5 percent thiobarbituric acid (TBA) was added to $0.5 \mathrm{~mL}$ of the supernatant. The mixture was boiled and cooled at $95{ }^{\circ} \mathrm{C}$. A spectrophotometer was used to measure the absorbance of all treated samples at 532 and $600 \mathrm{~nm}$. The absorption co-efficient, $155 \mathrm{mmol} / \mathrm{cm}$, was used to calculate the level of TBA:

$$
\mathrm{MDA}=\Delta(\mathrm{OD} 532-\mathrm{OD} 600) / 1.56 \times 10^{5}
$$




\subsection{Antioxidant Enzyme Activities}

For antioxidant enzyme activities, the sample of fresh leaf $(0.5 \mathrm{~g})$ was homogenized in $10 \mathrm{~mL}$ potassium phosphate buffer for enzyme extraction ( $\mathrm{pH}$ 7.8). After centrifugation for $15 \mathrm{~min}$ at $15,000 \mathrm{rpm}$, the extract supernatant was frozen at $-20^{\circ} \mathrm{C}$ in an ultra-low freezer.

The method proposed by Chance and Maehly [40] was used to determine the activity of the CAT enzyme. We combined $0.1 \mathrm{~mL}$ of plant extract with $1 \mathrm{~mL}$ of $5.9 \mathrm{mM} \mathrm{H}_{2} \mathrm{O}_{2}$ and $1.9 \mathrm{~mL}$ of $50 \mathrm{mM}$ phosphate buffer in a $50 \mathrm{~mL}$ flask $(7.0 \mathrm{pH})$. At $240 \mathrm{~nm}$, the absorbance was measured at 20-s intervals for two minutes. One unit of CAT activity was equal to a change of $0.01 \mathrm{~A} 240 \mathrm{Units} / \mathrm{min}$. The activities of CAT were then calculated and expressed in milligrams per milligram of total soluble protein.

The activity of POD enzyme was determined using a method proposed by [41]. A reaction mixture $\left(750 \mu \mathrm{L}\right.$ phosphate buffers $(7.0 \mathrm{pH})+100 \mu \mathrm{L} \mathrm{H}_{2} \mathrm{O}_{2}(5.9 \mathrm{mM})+100 \mu \mathrm{L}$ guicol $(0.5 \%)+50 \mu \mathrm{L}$ enzyme extract) was prepared to measure the activity of POD enzyme. The absorbance was then measured using a spectrophotometer at $470 \mathrm{~nm}$ for $2 \mathrm{~min}$ at 20 -s intervals. The activities of POD were then calculated and expressed in milligrams per milligram of total soluble protein.

The activity of APX enzyme was determined using a method proposed by [40,41]. A reaction mixture $\left(700 \mu \mathrm{L}\right.$ phosphate buffers $(7.0 \mathrm{pH})+100 \mu \mathrm{L} \mathrm{H}_{2} \mathrm{O}_{2}(5.9 \mathrm{mM})+100 \mu \mathrm{L}$ ascorbate $(0.5 \mathrm{mM})+100 \mu \mathrm{L}$ enzyme extract) was prepared to measure the activity of APX enzyme. The absorbance was then measured using a spectrophotometer at $290 \mathrm{~nm}$ for 2 min at 20-s intervals. The activities of APX were then calculated and expressed in milligrams per milligram of total soluble protein.

A reaction mixture $\left(400 \mu \mathrm{L} \mathrm{H}_{2} \mathrm{O}+350 \mu \mathrm{L}\right.$ phosphate buffer $+100 \mu \mathrm{L}$ methionine $+50 \mu \mathrm{L} \mathrm{NBT}+50 \mu \mathrm{L}$ enzyme extract $+50 \mu \mathrm{L}$ riboflavin) was prepared to measure the activity of the SOD enzyme [42]. The mixture was then exposed to light for $15 \mathrm{~min}$, with the decrease in absorbance measured at $560 \mathrm{~nm}$. A blank was made by omitting the enzyme extract. The activities of SOD were then calculated and expressed in milligrams per milligram of total soluble protein.

\subsection{Statistical Analysis}

A three-way fully randomized analysis of variance (ANOVA) with replication was carried out using CoStat V6.4 to test the influence of plant growth promoting Bacillus spp. strains isolated from textile wastewater on maize (Zea mays L.) under water deficit conditions. The Principle Component Analysis (PCA) and Pearson coefficient correlation among studied attributes were computed by using the IBM SPSS Statistics software windows version 25 (IBM Corp, Armonk, NY, USA).

\section{Results}

\subsection{Screening of Plant Beneficial Bacillus spp. Strains}

Bacterial strains were appeared as smooth, scatter, curved, and glittering colonies on the nutrient agar plates. Colonies isolated from mixed populations were obtained by characterizing and sub-culturing. Twelve isolates in total were obtained, and each isolate was used for further analysis. Four of those isolates with positive activity of important biochemical enzymes and efficient in plant growth promoting characteristics were selected for further studies (Table 2). The strains were identified as bacillus species based on the sequence similarity search in the NCBI database. The four isolated strains BEB1, BEB2, BEB3 and BEB4 showed $96.58 \%, 97.99 \%, 98.61 \%$ and $98.20 \%$ sequence identity with Bacillus cereus strain A22 (MG598445.1), Bacillus cereus strain YLB-P5 (KF376341.1), Bacillus tropicus strain SA31 (MK467555.1) and Bacillus thuringiensis strain a57 (KX057537.1), respectively. In phylogenetic trees, the 16S rRNA gene sequence is clustered with Bacillus species (Figure 1). The 16S rRNA sequences were submitted in the GenBank public database under the NCBI and received accession numbers (Table 2). 


\subsection{In Vitro Plant Growth Promoting Characteristics of Strains}

Production of ammonia by isolated strains was examined by missing the cultured supernatant with Nessler's reagent. The highest level of ammonia $(5.24 \mu \mathrm{mol} / \mathrm{mL})$ was produced by strain BEB3 within $48 \mathrm{~h}$, but, when estimated after a $72 \mathrm{~h}$ strain, BEB1 showed a maximum amount $(6.44 \mu \mathrm{mol} / \mathrm{mL})$ of ammonia produced in the culture medium. In terms of in vitro, plant-beneficial traits under normal and water stress (15\% PEG6000) followed the somewhat similar trend for IAA synthesis in culture medium. In this assay, four selected isolates were able to produce IAA in the culture medium only in the presence of substrate L-Tryptophan ( $1 \mathrm{~g} / \mathrm{L})$. However, isolates BEB1 demonstrated IAA production 54.09 and $33.63 \mu \mathrm{g} / \mathrm{mL}$ under normal and the stress of PEG6000, respectively. However, varying nitrogenase activity, examined on a nitrogen-free malate medium, was detected by isolated strains in both liquid and solid media. In liquid media strain, BEB1 showed maximum atmospheric nitrogen fixation in terms of positive bacterial cell growth (OD $600 \mathrm{~nm}$ ). On the other hand, on nitrogen-free malate, the agar plate BEB4 strain showed the highest blue halo zone diameter by nitrogenase enzyme activity (Table 2). For in-vitro phosphate solubilization assay, bacterial isolates formed halo-zones of varying diameters on NBRIP media plates; however, the maximum physiological competence solubilization index (2.54) and halo-zone formation was found in strain BEB3. Strains BEB1, BEB2 and BEB4 were able to demonstrate solubilization indexes 2.23, 2.33 and 2.47, respectively.

Table 2. Characterization of bacterial strain for enzyme production and in vitro PGP traits.

\begin{tabular}{|c|c|c|c|c|}
\hline Characteristics & BEB1 & BEB2 & BEB3 & BEB4 \\
\hline \multicolumn{5}{|l|}{ Cell Morphology } \\
\hline Gram stain & + & + & + & + \\
\hline Shape & Rod & Rod & Rod & Rod \\
\hline \multicolumn{5}{|l|}{ Biochemical tests } \\
\hline Catalase & +++ & +++ & +++ & +++ \\
\hline Amylase & +++ & ++ & +++ & +++ \\
\hline Exopolysaccharides & +++ & ++ & +++ & ++ \\
\hline Indole test & + & - & - & - \\
\hline Proteases (Zone mm) & $18 \pm 1$ & $15 \pm 1$ & $19 \pm 1$ & $17 \pm 1$ \\
\hline \multicolumn{5}{|l|}{ PGP Traits } \\
\hline Ammonia Production $48 \mathrm{~h}(\mu \mathrm{mol} / \mathrm{mL})$ & 5.22 & 5.20 & 5.24 & 5.21 \\
\hline Ammonia Production $72 \mathrm{~h}(\mu \mathrm{mol} / \mathrm{mL})$ & 6.44 & 6.41 & 6.35 & 6.29 \\
\hline IAA Production (Without Trp) & - & - & - & - \\
\hline IAA Production $(\operatorname{Trp})(\mu \mathrm{g} / \mathrm{mL})$ & 54.09 & 20.70 & 22.13 & 21.41 \\
\hline IAA Production $(\operatorname{Trp}+15 \%$ PEG) $(\mu \mathrm{g} / \mathrm{mL})$ & 33.63 & 12.76 & 13.65 & 13.21 \\
\hline Nitrogen Fixation $(\mathrm{mm} \pm \mathrm{SD})$ & $26.33 \pm 1.52$ & $20.66 \pm 1.52$ & $19.66 \pm 1.52$ & $29.33 \pm 1.52$ \\
\hline Nitrogen Fixation (OD 600 nm) & 0.975 & 0.453 & 0.541 & 0.424 \\
\hline Phosphate solubilization (SI $\pm \mathrm{SD}$ ) & $2.23 \pm 0.082$ & $2.33 \pm 0.082$ & $2.52 \pm 0.082$ & $2.47 \pm 0.082$ \\
\hline \multicolumn{5}{|l|}{ Molecular } \\
\hline BLAST Comparison (16S rDNA) & B. cereus & B. cereus & B. tropicus & B. thuringiensis \\
\hline Accession Number & MW350048 & MW350049 & MW350050 & MW350051 \\
\hline
\end{tabular}

$\mathrm{SI}=$ solubilization index; $\mathrm{SD}$ = standard deviation; Trp = tryptophan; PEG; polyethylene glycol; OD = optical density;,+++ , and $+++=$ positive, high positive and strong positive, respectively. 


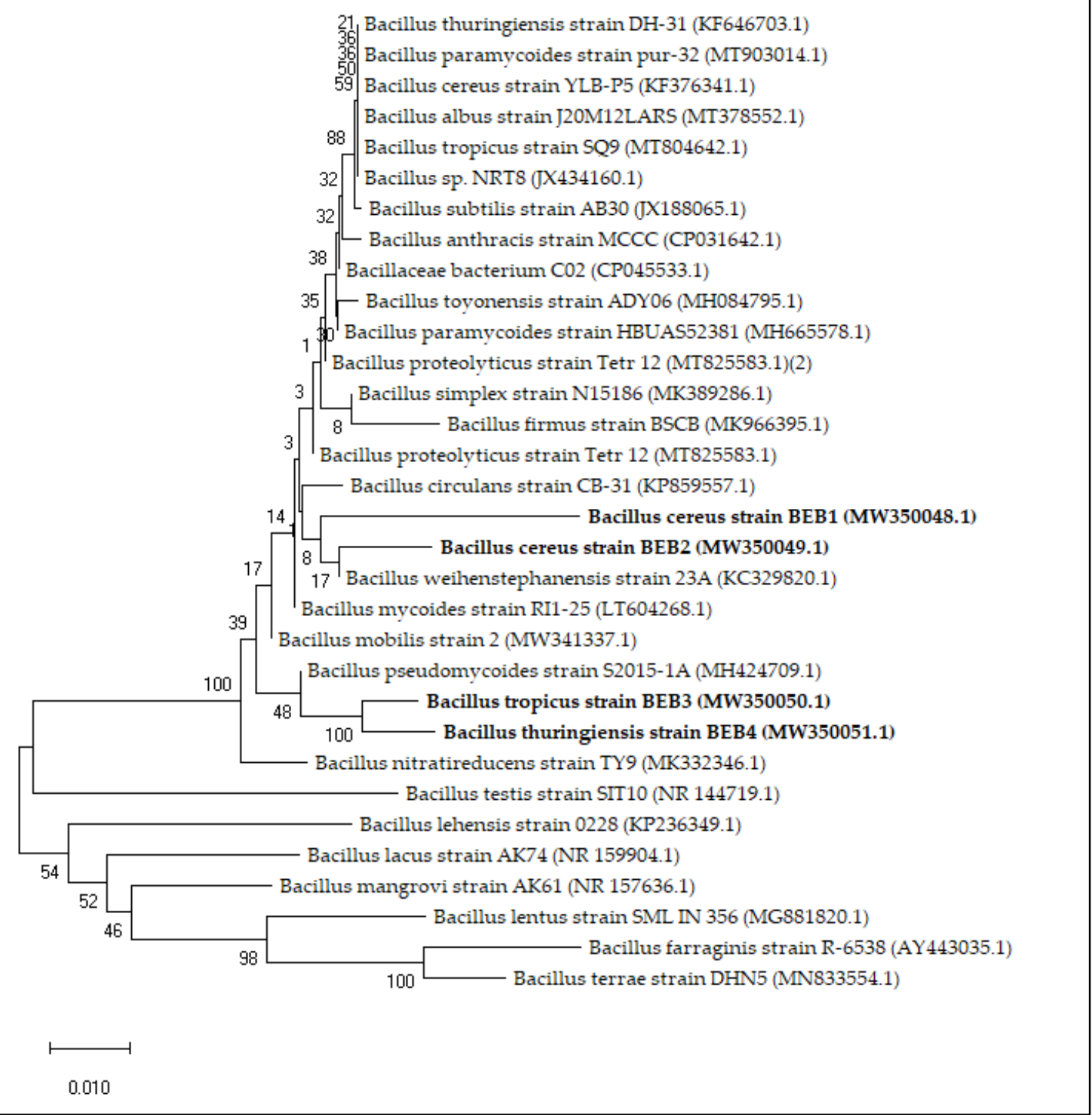

Figure 1. Phylogenetic tree based on a $16 \mathrm{~S}$ rRNA nucleotide sequences showing the position of isolated strains among the most relevant species by BLAST comparative analysis. The tree was constructed using the Neighbor-Joining method and bootstrap values (expressed as percentage of 100 replications) are shown at branching points.

\subsection{In Vitro Drought Tolerance Testing of Bacterial Strains}

The four isolated bacterial strains showing best plant growth promoting properties were also analyzed for in vitro drought tolerance by using polyethylene glycol (PEG 6000). The growth of tested strains (OD $600 \mathrm{~nm}$ ) on varying water potential by polyethylene glycol was shown in (Figure 2). Different concentrations (0,5\%,10\%, 15\%, 20\%, and $25 \%$ ) of PEG 6000 were used in LB broth medium to control water potential. Strain BEB1 grew well and showed a maximum tolerance to the drought stress even at the lowest water potential. 


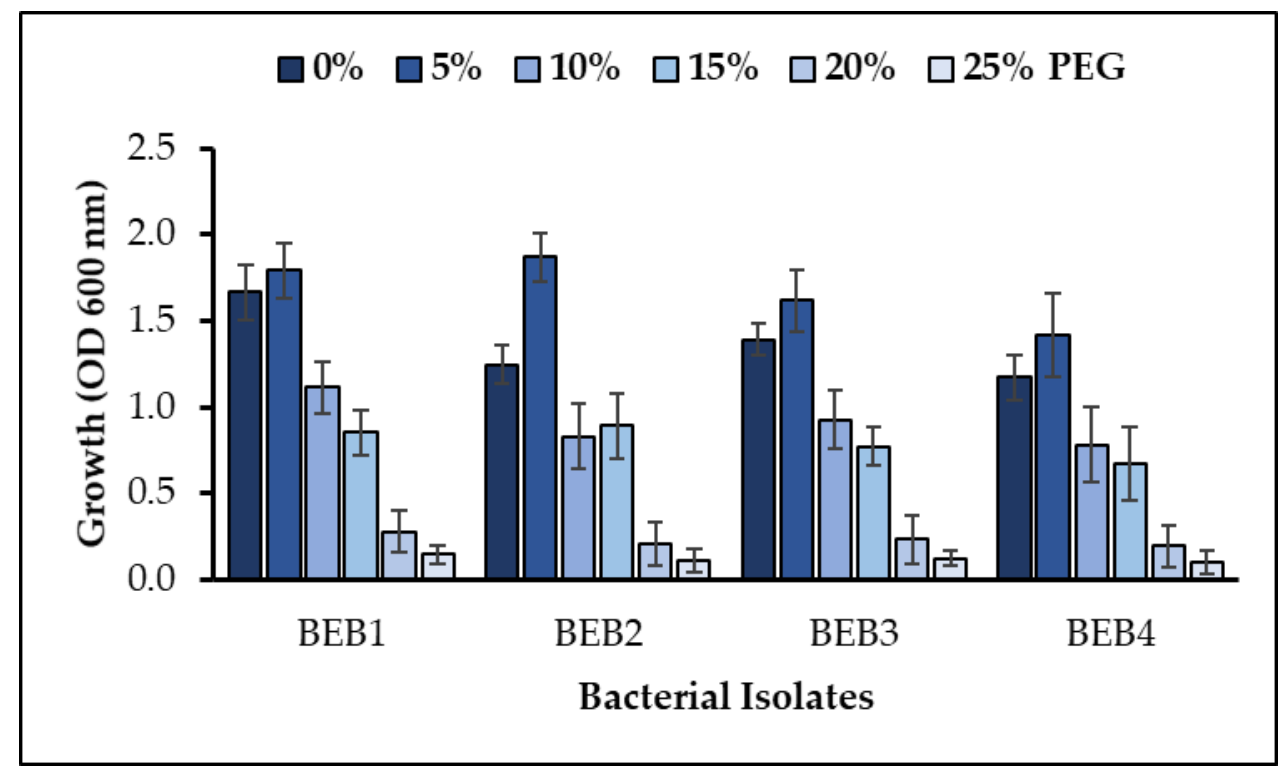

Figure 2. Relative growth of wastewater isolated bacterial strains in different concentrations of polyethylene glycol (PEG 6000) in culture medium (values are the mean of three replicates and the bar represents the standard error); LSD value $\leq 0.05$.

\subsection{Plant Physiological Parameters Influenced by Bacterial Inoculation}

Plant growth decreased significantly under water stress (5-8\% water content in the soil); reductions in plant shoot length of V1: FH-1016 (13.89\%), V2: YH-5427 (9.75\%), and root length V1 (15.09\%), V2 (7.23\%) were observed in uninoculated plants (Table 3, Figure 3A,B). However, bacterial inoculation improved the shoot as well as root lengths of both cultivars of maize (Zea mays L.) under water deficit regimes. The inoculation with Bacillus spp. BEB1 (V1:33.8, V2: 42.48\%), BEB2 (39.6, 22.34\%), BEB3 (33.1, 37.52\%) and BEB4 $(26.87,33.14 \%)$ increased shoot length on stressed plants of both maize cultivars when compared to the uninoculated stressed control (Table 3, Figure 3A). Plant root length increased significantly by inoculation with Bacillus spp. BEB1 (17.7, 21.16\%), BEB2 (24.64, $14.03 \%)$, BEB3 $(22.99,39.87 \%)$ and BEB4 $(31.28,13.81 \%)$ in both cultivars when compared with the uninoculated drought control (Table 3, Figure 3B).

Bacillus spp. inoculation increased fresh and dry biomass in both cultivars of maize plants under drought stress. Plants treated with PGPB inoculation recorded the improved fresh biomass, as shoot fresh weight followed by Bacillus sp. BEB1 (47.96, 48.0\%), BEB2 (56.12, 29.0\%), BEB3 (35.20, 52.5\%), BEB4 (28.57, 39.5\%) and root fresh weight Bacillus sp. BEB1 (36.73, 14.66\%), BEB2 (21.64, 8.62\%), BEB3 (17.14, 23.28\%), BEB4 (13.88, 9.48\%) when compared with the uninoculated drought control (Table 3, Figure 3C). Furthermore, plant shoot dry biomass accumulation increased significantly in stressed plants treated with Bacillus sp. BEB1 (103.44, 103.5\%), BEB2 (71.73, 41.9\%), BEB3 $(65.25,86.39 \%)$ and BEB4 (57.14, 70.5\%) when compared with the uninoculated drought control. Furthermore, the inoculation with Bacillus sp. BEB1 (88.01, 57.65\%), BEB2 (33.80, 19.48\%), BEB3 (43.17, $50.67 \%)$ and BEB4 $(39.18,33.81 \%)$ significantly increased plant root dry weight in both maize cultivars when compared to the uninoculated drought control (Table 3, Figure 3F). 
Table 3. Mean squares from three-way analysis of variance of data for different physiological, biochemical and antioxidant parameters of maize (Zea mays L.) plants inoculated with Bacillus spp. strains under well-watered (control, 15-18\% water content in soil) and water deficit (stress, 5-8\% water content in soil) conditions.

\begin{tabular}{|c|c|c|c|c|c|c|}
\hline $\begin{array}{l}\text { Source of } \\
\text { Variation }\end{array}$ & df & Shoot Length & Root Length & Shoot FW & Root FW & Shoot DW \\
\hline Cultivars (C) & 1 & $40.83 *$ & $0.020 \mathrm{~ns}$ & $1.666 \mathrm{~ns}$ & $0.158^{* * *}$ & $6.666 \mathrm{~ns}$ \\
\hline Drought (D) & 1 & $2.281 \mathrm{~ns}$ & $33.00 * *$ & $0.078 *$ & $0.152^{* * *}$ & $6.666 \mathrm{~ns}$ \\
\hline Bacillus spp. (B) & 4 & $85.87^{* * *}$ & $26.16^{* * *}$ & $0.115^{* * *}$ & $0.073^{* * *}$ & $0.005 \mathrm{~ns}$ \\
\hline$C \times D$ & & $10.00 \mathrm{~ns}$ & $9.680 \mathrm{~ns}$ & $0.005 \mathrm{~ns}$ & & $6 \times 10^{-5 * * *}$ \\
\hline $\mathrm{C} \times \mathrm{B}$ & 1 & $9.781 \mathrm{~ns}$ & $6.978 \mathrm{~ns}$ & $0.016 \mathrm{~ns}$ & $0.008 \mathrm{~ns}$ & $1.733 \mathrm{~ns}$ \\
\hline $\mathrm{D} \times \mathrm{B}$ & 4 & $13.24 \mathrm{~ns}$ & $2.365 \mathrm{~ns}$ & $0.015 \mathrm{~ns}$ & $0.003 \mathrm{~ns}$ & $1.333 \mathrm{~ns}$ \\
\hline $\mathrm{C} \times \mathrm{D} \times \mathrm{B}$ & 4 & $6.141 \mathrm{~ns}$ & $2.681 \mathrm{~ns}$ & $0.004 \mathrm{~ns}$ & $0.011 \mathrm{~ns}$ & $6 \times 10^{-5} \mathrm{~ns}$ \\
\hline $\begin{array}{l}\text { Source of } \\
\text { Variation }\end{array}$ & $\mathrm{df}$ & Root DW & Chl a & Chl b & Total Chl & Carotenoids \\
\hline Cultivars (C) & 1 & $0.001^{* * *}$ & $3.174 \mathrm{~ns}$ & $1.815 \mathrm{~ns}$ & $4.873 \mathrm{~ns}$ & $0.080 \mathrm{~ns}$ \\
\hline Drought (D) & 1 & $0.001^{* * *}$ & $0.077^{* * *}$ & $0.014^{* * *}$ & $0.024^{* * *}$ & $10.41^{* * *}$ \\
\hline Bacillus spp. (B) & 4 & $0.005^{* * *}$ & $0.027^{* * *}$ & $6.518 \mathrm{~ns}$ & $0.020^{* * *}$ & $1.437^{* * *}$ \\
\hline$C \times D$ & & $2.2 \mathrm{~ns}$ & $0.001 \mathrm{~ns}$ & $0.002 \mathrm{~ns}$ & $3.601 \mathrm{~ns}$ & $0.864 \mathrm{~ns}$ \\
\hline $\mathrm{C} \times \mathrm{B}$ & 1 & $1.3 \mathrm{~ns}$ & $2.144 \mathrm{~ns}$ & $2.184 \mathrm{~ns}$ & $4.35 \mathrm{~ns}$ & $0.111 \mathrm{~ns}$ \\
\hline $\mathrm{D} \times \mathrm{B}$ & 4 & $2.5 \mathrm{~ns}$ & $0.002 * * *$ & $2.123 \mathrm{~ns}$ & $0.003^{* *}$ & $0.201 \mathrm{~ns}$ \\
\hline $\mathrm{C} \times \mathrm{D} \times \mathrm{B}$ & 4 & $1.6 \mathrm{~ns}$ & $1.298 \mathrm{~ns}$ & $1.596 \mathrm{~ns}$ & $1.768 \mathrm{~ns}$ & $0.058 \mathrm{~ns}$ \\
\hline $\begin{array}{l}\text { Source of } \\
\text { Variation }\end{array}$ & $\mathrm{df}$ & Flavonoids & TSS & TSP & AsA & MDA \\
\hline Cultivars (C) & 1 & $403.0^{* * *}$ & $85,126^{* * *}$ & $6242 * * *$ & $93.50 * * *$ & $0.140 \mathrm{~ns}$ \\
\hline Drought (D) & 1 & $67.20 * * *$ & $80,227 * * *$ & $12,973 * * *$ & $3749^{* * *}$ & $13.72 * * *$ \\
\hline Bacillus spp. (B) & 4 & $61.23^{* * *}$ & $33,266 * * *$ & $17,168^{* * *}$ & $361.7^{* * *}$ & $9.156^{* * *}$ \\
\hline $\mathrm{C} \times \mathrm{D}$ & & $4.873^{* *}$ & $4968^{* * *}$ & $11.26 \mathrm{~ns}$ & $117.3^{* * *}$ & $0.121 \mathrm{~ns}$ \\
\hline $\mathrm{C} \times \mathrm{B}$ & 1 & $3.821^{* * *}$ & $19,325 * * *$ & $780.7^{* * *}$ & $160.2^{* * *}$ & $0.465 \mathrm{~ns}$ \\
\hline $\mathrm{D} \times \mathrm{B}$ & 4 & $10.23^{* * *}$ & $3273^{* * *}$ & $2614^{* * *}$ & $59.83^{* * *}$ & $0.369 \mathrm{~ns}$ \\
\hline $\mathrm{C} \times \mathrm{D} \times \mathrm{B}$ & 4 & $30.26^{* * *}$ & $2013^{* * *}$ & $2550 * * *$ & $84.21^{* * *}$ & $0.120 \mathrm{~ns}$ \\
\hline $\begin{array}{l}\text { Source of } \\
\text { Variation }\end{array}$ & $\mathrm{df}$ & $\mathrm{H}_{2} \mathrm{O}_{2}$ & CAT & POD & APX & SOD \\
\hline Cultivars (C) & 1 & $3.504^{* * *}$ & $0.596^{* * *}$ & $1.134^{* *}$ & $3.243^{* * *}$ & $1.666 \mathrm{~ns}$ \\
\hline Drought (D) & 1 & $82.83^{* * *}$ & $25.53^{* * *}$ & $522.3^{* * *}$ & $62.07^{* * *}$ & $219.6^{* * *}$ \\
\hline Bacillus spp. (B) & 4 & $11.78^{* * *}$ & $11.01 * * *$ & $36.43^{* * *}$ & $14.33^{* * *}$ & $99.05^{* * *}$ \\
\hline $\mathrm{C} \times \mathrm{D}$ & & $0.060 \mathrm{~ns}$ & $0.233^{* *}$ & $15.39 * * *$ & $0.019 \mathrm{~ns}$ & $5.985 \mathrm{~ns}$ \\
\hline $\mathrm{C} \times \mathrm{B}$ & 1 & $0.072 * *$ & $0.406^{* * *}$ & $4.037^{* * *}$ & $0.298^{* * *}$ & $5.614 \mathrm{~ns}$ \\
\hline $\mathrm{D} \times \mathrm{B}$ & 4 & $3.186^{* * *}$ & $0.414^{* * *}$ & $0.768^{* *}$ & $0.742^{* * *}$ & $7.023 \mathrm{~ns}$ \\
\hline $\mathrm{C} \times \mathrm{D} \times \mathrm{B}$ & 4 & $0.268^{* * *}$ & $0.186^{* * *}$ & $1.530 * * *$ & $0.833^{* * *}$ & $5.334 \mathrm{~ns}$ \\
\hline
\end{tabular}

$\mathrm{ns}=$ non-significant; ${ }^{*}, * *$ and ${ }^{* * *}=$ significant at $0.05,0.01$ and 0.001 levels, respectively. 
$\square$ Control $\square$ Stress
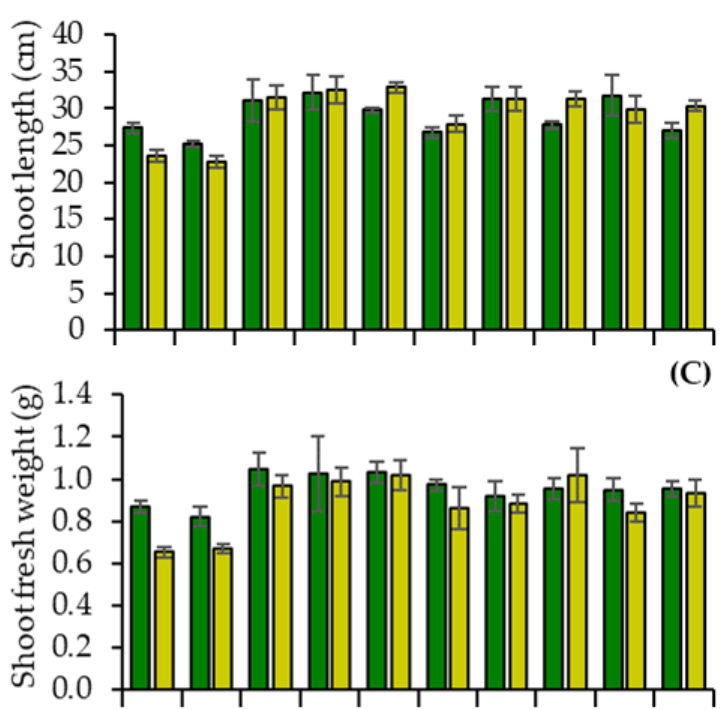

(E)

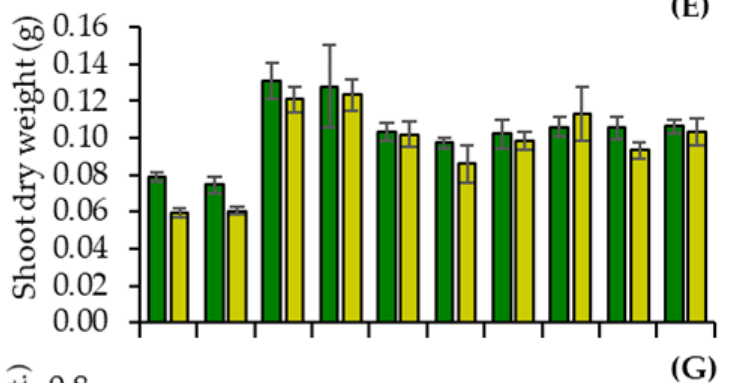

芆 0.8

空 0.7 -

离 0.6

๘ 0.4

글 0.3

कै 0.2 -

흐 0.1
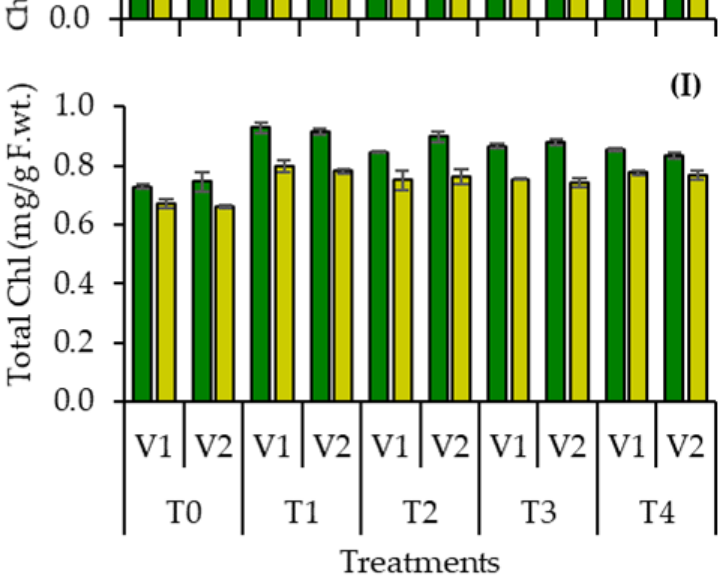

$\square$ Control $\square$ Stress

(B)

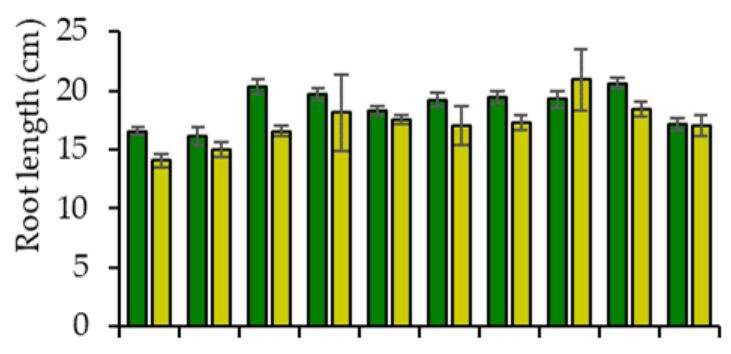

(D)
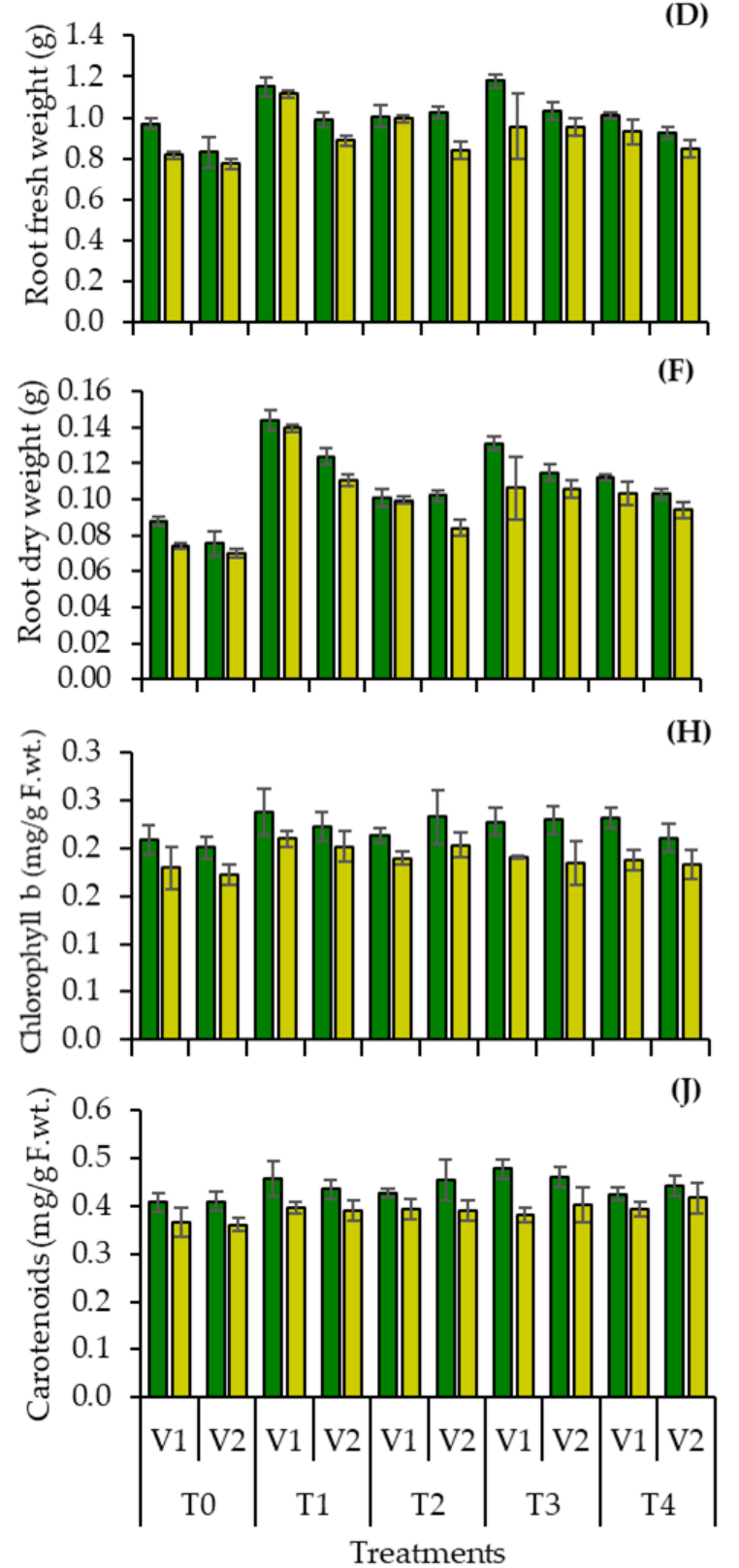

Figure 3. (A) shoot length, (B) root length, (C) shoot fresh weight, (D) root fresh weight, (E) shoot dry weight, (F) root dry weight, $(\mathbf{G})$ Chlorophyll a, $(\mathbf{H})$ chlorophyll b, (I) total chlorophyll, and (J) carotenoid contents of two cultivars of maize (Zea mays L.) inoculated with Bacillus spp. strains subjected to water stress condition (Mean \pm S.E). Here T0 = uninoculated control, T1 = Bacillus cereus strain BEB1, T2 = Bacillus cereus strain BEB2, T3 = Bacillus tropicus strain BEB3, T4 = Bacillus thuringiensis strain BEB4. LSD value $\leq 0.05$. 


\subsection{Estimation of Plant Photosynthetic Pigments}

Photosynthetic pigment synthesis decreased in uninoculated drought-stressed followed by significant reduction in chlorophyll a, chlorophyll $b$, total chlorophyll and carotenoid contents in both maize cultivars when compared to the uninoculated control (Table 3, Figure 3). PGPR strains significantly $(p \leq 0.001)$ improved chlorophyll $(\mathrm{a}, \mathrm{b}$ \& total) and carotenoid contents under both water regimes. Both maize cultivars had higher chlorophyll a, b, total chlorophyll and carotenoid contents as compared to the uninoculated plants under water stress conditions. The maximum improvement in chlorophyll a with Bacillus sp. BEB1 in V1 (32.76\%), chlorophyll b with Bacillus sp. BEB2 in V2 (15.8\%) and total chlorophyll contents was observed in plants inoculated with Bacillus sp. BEB1 (27.36, $22.82 \%$ ) when compared to the uninoculated control (Table 3, Figure 3G-I). In contrast, plants inoculated with Bacillus sp. BEB3 (17.14, 12.12\%) showed improved carotenoid contents when compared to the uninoculated control (Table 3, Figure 3J).

\subsection{Biochemical Attributes Influenced by Bacterial Inoculation}

A significant reduction was observed in flavonoid contents in both maize cultivars when inoculated with Bacillus spp. BEB1 (48.79, 22.25\%), BEB2 (38.33, 29.62\%), BEB3 (35.15, $31.57 \%)$ and BEB4 $(39.55,22.67 \%)$ under water deficit conditions when compared to the uninoculated drought control which was accumulated $(46.67,28.85 \%)$ in uninoculated stress plants (Table 3, Figure 4A). Plant biochemical parameters decreased significantly under water stress (5-8\% water content in the soil); reductions in plant total soluble sugars (51.91, $31.07 \%)$, total soluble protein $(32.42,46.24 \%)$ and ascorbic acid contents $(22.91,34.94 \%)$ were observed in uninoculated plants (Table 3, Figure 4B-D). The inoculation with Bacillus spp. BEB1 (150.79, 123.88\%), BEB2 (86.67, 31.06\%), BEB3 (59.68, 39.40\%) and BEB4 (253.02, $17.31 \%$ ) increased total soluble sugars in stressed plants of both maize cultivars when compared to the uninoculated stressed control (Table 3, Figure 4B). An increase in total soluble protein contents was observed under both well water and water deficit condition with the inoculation of Bacillus spp. BEB1 (39.60, 89.64\%), BEB2 (10.40, 41.45\%), BEB3 (34.68, $42.55 \%)$ and BEB4 $(52.17,70.55 \%)$ when compared to the uninoculated drought control (Table 3, Figure 4C). Plant ascorbic acid contents increased significantly by inoculation with Bacillus sp. BEB1 $(26.61,43.29 \%)$, BEB2 $(35.27,26.57 \%)$, BEB3 $(18.22,51.29 \%)$ and BEB4 $(23.26,39.57 \%)$ in both cultivars (V1, V2) when compared with the uninoculated drought control (Table 3, Figure 4D). A significant difference was observed among all treatments, and among both cultivars in biochemical attributes estimated under a well-watered regime and under water deficit stress.

Malonaldehyde and hydrogen peroxide contents accumulation increased significantly in uninoculated drought-stressed followed by MDA $(23.83,19.89 \%)$ and $\mathrm{H}_{2} \mathrm{O}_{2}(94.76,100 \%)$ in both maize cultivars when compared to the uninoculated control (Table 3, Figure 4). Due to inoculation of isolated PGPR bacterial species, MDA contents and $\mathrm{H}_{2} \mathrm{O}_{2}$ were lowered under both well-watered and water deficit conditions. Plants treated with Bacillus sp. BEB1 (50.78, 59.14\%), BEB2 (50.26, 45.16\%), BEB3 (48.19, 40.32\%) and BEB4 (39.38, $30.65 \%$ ) lowered the malonaldehyde contents when compared to the uninoculated control (Table 3, Figure 4E). In contrast, plants inoculated with Bacillus sp. BEB1 (37.04, 44.71\%), BEB2 $(32.44,31.94 \%)$, BEB3 $(45.75,41.07 \%)$ and BEB4 $(39.24,36.18 \%)$ showed decreased hydrogen peroxide generation when compared to the uninoculated drought control (Table 3 , Figure 4F). A significant difference was observed among maize cultivars, and bacterial treatments were found to be varying significantly in both cultivars specifically under water deficit conditions. 
$\square$ Control $\square$ Stress
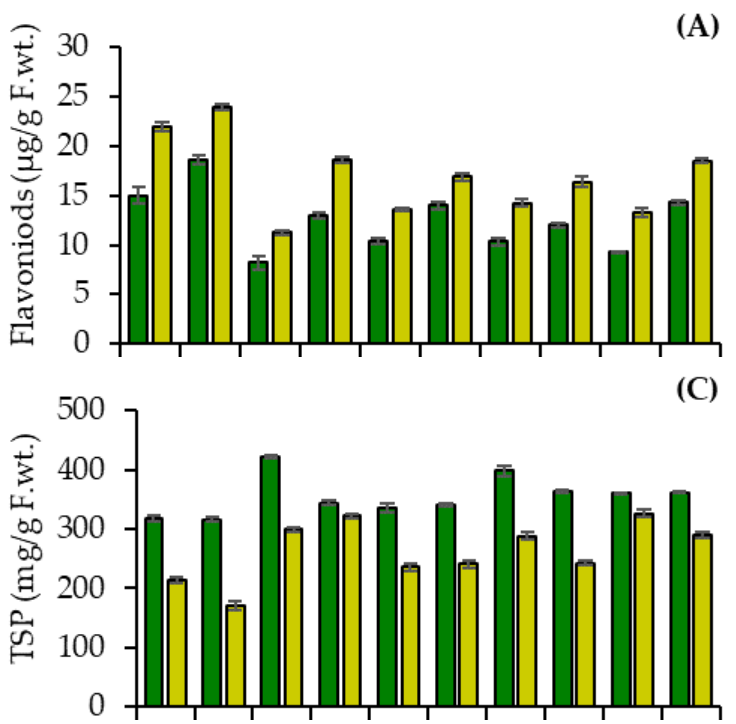

(E)
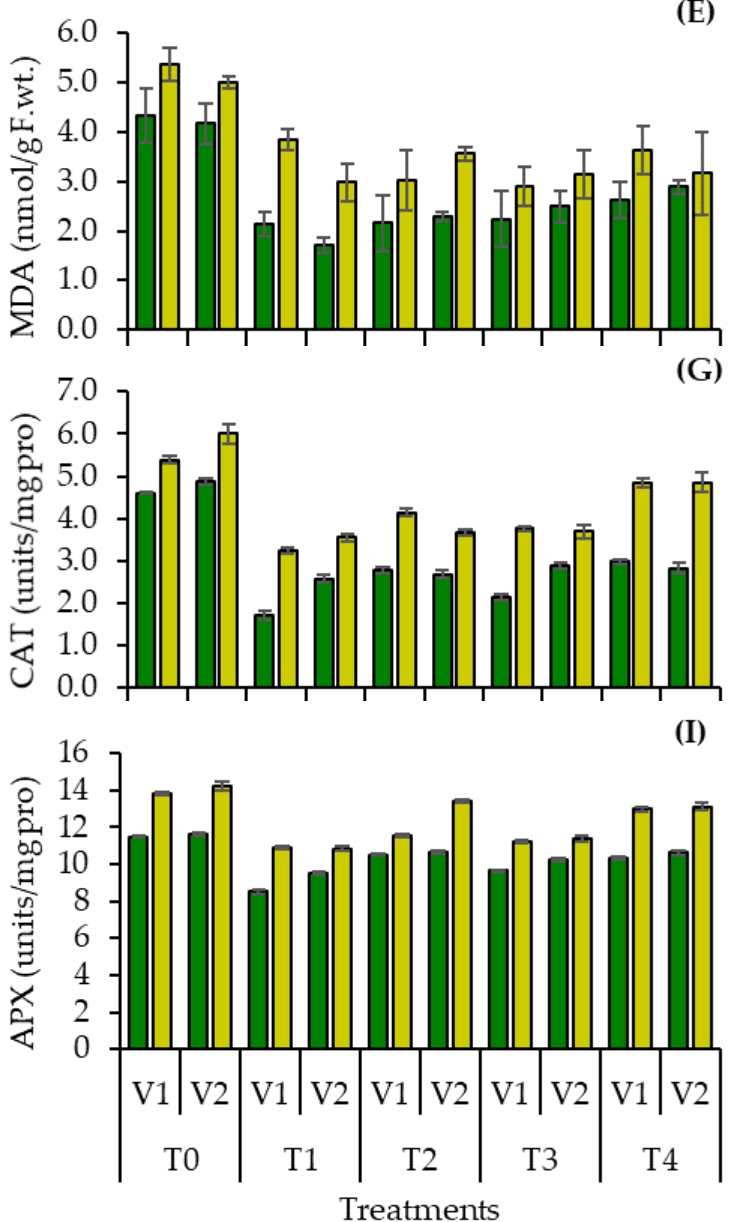

$\square$ Control $\square$ Stress
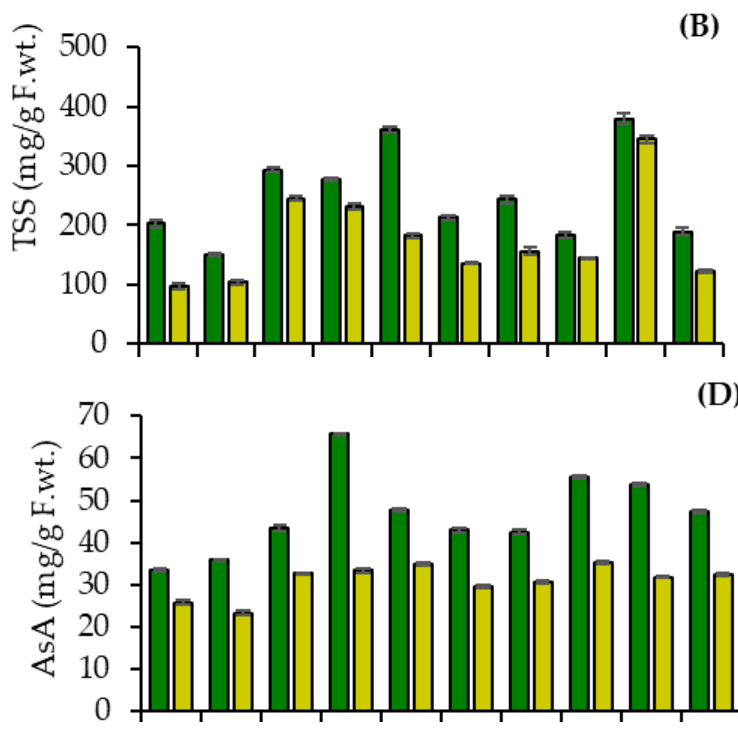

(F)
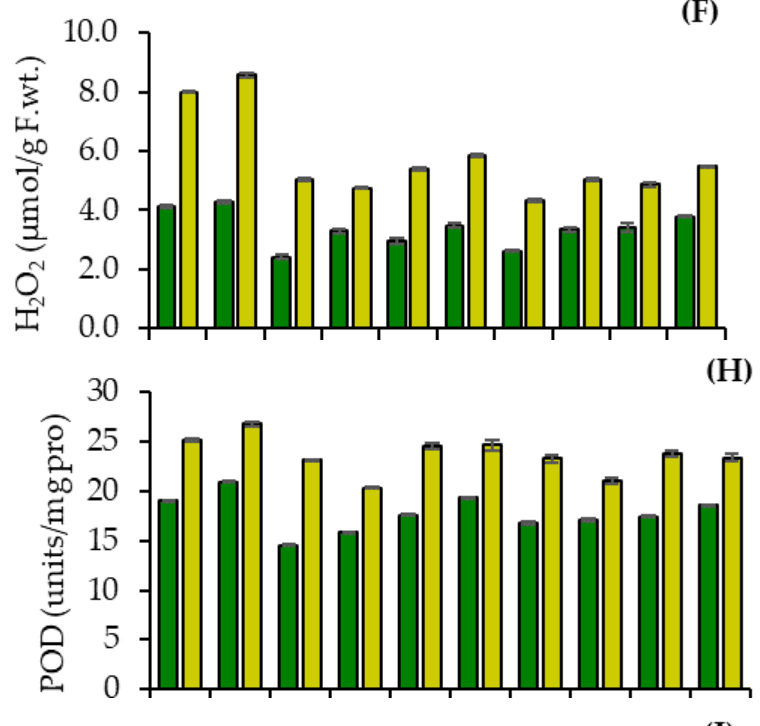

(J)

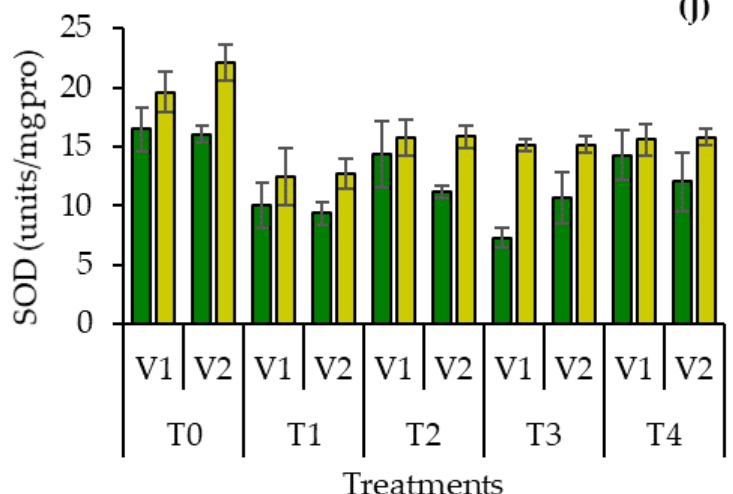

Figure 4. (A) Flavonoids, (B) total soluble sugars, (C) total soluble proteins and (D) ascorbic acid (E) malonaldehyde, $(\mathbf{F})$ hydrogen peroxide contents $(\mathbf{G})$ catalase, $(\mathbf{H})$ peroxidase, $(\mathbf{I})$ ascorbate peroxidase, and (J) superoxide dismutase enzyme activity of two cultivars of maize (Zea mays L.) inoculated with Bacillus spp. strains subjected to water stress condition (Mean $\pm \mathrm{S}$.E). Here, T0 = uninoculated control, T1 = Bacillus cereus strain BEB1, T2 = Bacillus cereus strain BEB2, T3 = Bacillus tropicus strain BEB3, T4 = Bacillus thuringiensis strain BEB4. LSD $\leq 0.05$. 


\subsection{Antioxidant Enzyme Activities of Plant Leaf Extract}

The antioxidant response to drought stress was stimulated in uninoculated plants, increasing CAT $(16.85,23.01 \%)$, POD $(32.21,27.86 \%)$, APX (20.36, 22.45\%) and SOD (19.16, $37.42 \%$ ) activities (Table 3, Figure 4). The trend in increase in enzyme activities in both cultivars was significantly different. Moreover, Bacillus spp. inoculation showed the mitigation of the plant enzymatic antioxidant responses under drought stress. The reductions in CAT activity were recorded in plants inoculated with Bacillus sp. BEB1 $(62.96,47.34 \%)$, BEB2 $(39.67,44.96 \%)$, BEB3 $(53.51,40.72 \%)$ and BEB4 $(35.13,42.02 \%)$ (Table 3, Figure $4 \mathrm{G})$ when compared to the uninoculated control. The higher reductions in POD and APX activity were recorded in plants inoculated with Bacillus sp. BEB1, which was $(23.46,24.44 \%)$ and $(25.95,18.10 \%)$, respectively, as compared to the uninoculated control (Table 3, Figure 4H,I). In addition, a significant reduction in SOD activity was observed in plants inoculated with Bacillus sp. BEB1 (38.92, 41.72\%), BEB2 (12.57, 30.06\%), BEB3 $(55.69,33.74 \%)$ and BEB4 $(13.17,25.15 \%)$ when compared to the drought control (Table 3, Figure 4J).

\subsection{Principal Component Analysis and Pearson Coefficient Correlation}

The values of Pearson correlation of all the studied parameters with their significance at probability levels $(p)<0.05,0.01,0.001$ are presented (Table 4$)$. It clearly shows that the plant biomass has a positive significant correlation with studied physiological attributes like shoot and root length, chlorophyll a, total chlorophyll as well as biochemical attributes such as total soluble sugars, total soluble proteins and ascorbic acid contents. However, shoot biomass was negatively correlated with the MDA, $\mathrm{H}_{2} \mathrm{O}_{2}$ and flavonoid contents. Moreover, the shoot dry weight also has a negative significant correlation with antioxidant enzyme activities CAT, POD, APX and SOD. Correlation studies presented in (Figure 5) generated through PCA show that the studied attributes are categorized into two major groups. The first component of the PCA explained 58.3\%, while the second component explained $10.4 \%$ of the variance.

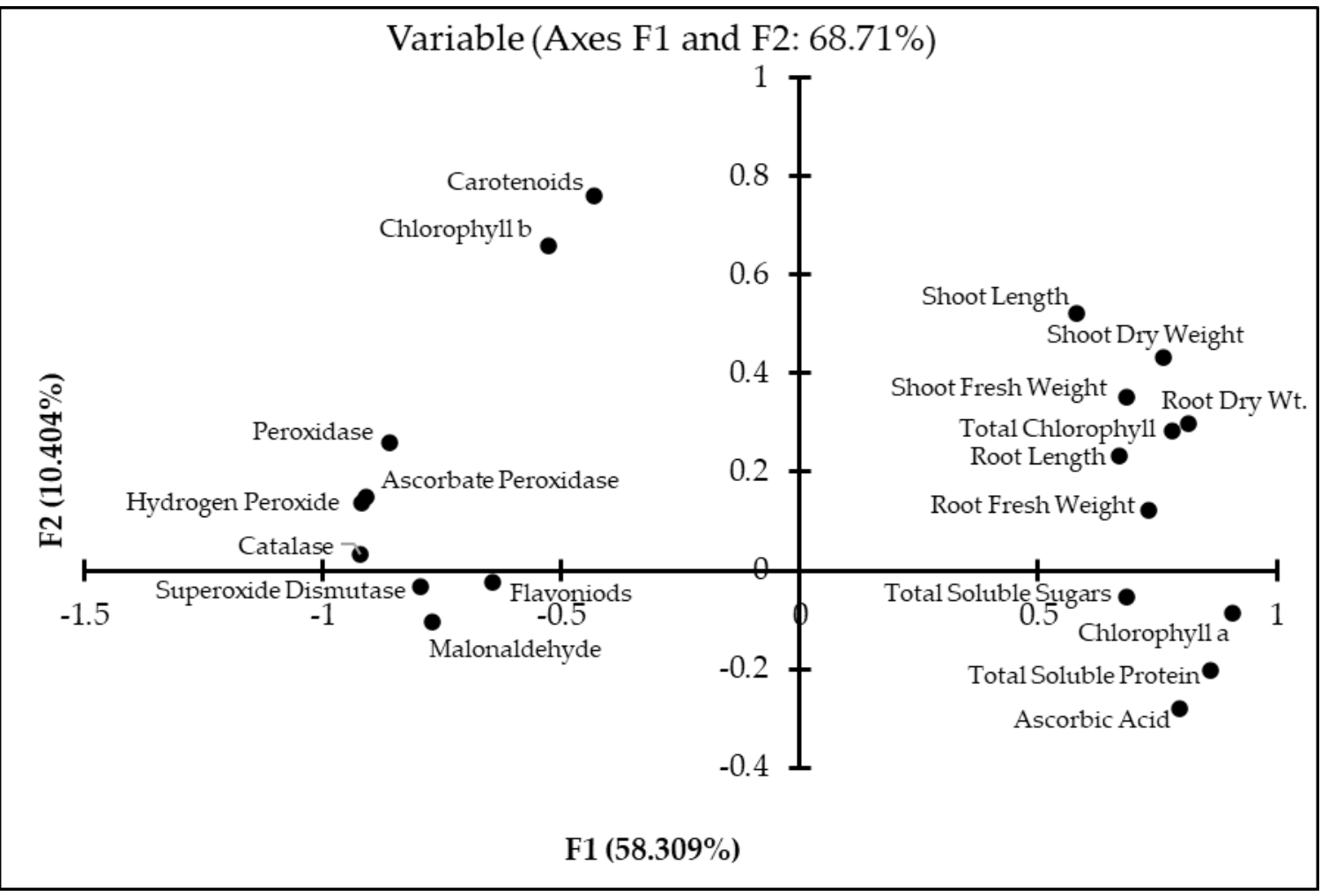

Figure 5. Principal component analysis (PCA) of studied attributes of maize inoculated with Bacillus spp. strains under drought stress. 
Table 4. Pearson coefficient correlation values of estimated attributes of maize (Zea mays L.) inoculated with Bacillus spp. strains showing significance differences under drought stress.

\begin{tabular}{|c|c|c|c|c|c|c|c|c|c|c|c|c|c|c|c|c|c|c|c|c|}
\hline & RFW & SFW & RDW & SDW & RL & SL & Chla & Chlb & TChl & Caro & Flav & TSS & TSP & $\mathrm{H}_{2} \mathrm{O}_{2}$ & MDA & AsA & CAT & APX & POD & SOD \\
\hline RFW & $\begin{array}{l}1.000 \\
0.50 * * * *\end{array}$ & & & & & & & & & & & & & & & & & & & \\
\hline RDW & 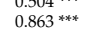 & $\begin{array}{l}1.000 \\
0.571^{* * * *}\end{array}$ & 1.000 & & & & & & & & & & & & & & & & & \\
\hline SDW & $0.531 \%$ & $0.900^{* * * *}$ & $0.765^{* * 4 *}$ & 1.000 & & & & & & & & & & & & & & & & \\
\hline $\mathrm{RL}$ & 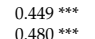 & $\begin{array}{l}0.602 * * * * * * \\
0.688 * * *\end{array}$ & $\begin{array}{l}0.519 * * * * \\
0.632 * * *\end{array}$ & $0.607 * * *+1$ & $\begin{array}{l}1.000 \\
0.570 * * * *\end{array}$ & & & & & & & & & & & & & & & \\
\hline $\begin{array}{l}\text { SL } \\
\text { Chla }\end{array}$ & $\begin{array}{l}0.480 * * * * * * * \\
0.561^{* * *}\end{array}$ & 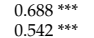 & $\begin{array}{l}0.632 * * * * \\
0.683 * *\end{array}$ & $\begin{array}{l}0.762 * * * * \\
0.63 * * *\end{array}$ & $\begin{array}{l}0.576 * * * * \\
0.594 * * *\end{array}$ & $\begin{array}{l}1.000 \\
0.401 * * * * *\end{array}$ & & & & & & & & & & & & & & \\
\hline Chlb & $\begin{array}{l}0.561 \\
-0.327 * * *\end{array}$ & $\begin{array}{l}0.542 \\
-0.313 * * * \\
* *\end{array}$ & $\begin{array}{c}0.6833^{* *} \\
-0.291 * *\end{array}$ & $\begin{array}{c}0.632^{* * * *} \\
-0.281^{* * *}\end{array}$ & $\begin{array}{c}0.594 * * * * * \\
-0.305 * *\end{array}$ & $\begin{array}{c}0.40101^{* * *} \\
-0.158 \mathrm{~ns}\end{array}$ & $\begin{aligned} & 1.000 \\
&-0.556 * * *\end{aligned}$ & & & & & & & & & & & & & \\
\hline TChl & $0.482 *+4$ & 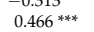 & $\begin{array}{c}-0.291 * * 4 \% \\
0.649 * *\end{array}$ & $\begin{array}{r}-0.281 * * * * \\
0.596 * *\end{array}$ & 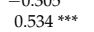 & $\begin{array}{c}-0.158 \mathrm{~ns} \\
0.390 * * *\end{array}$ & $\begin{array}{l}-0.556 \\
0.874 * * * * *\end{array}$ & $\begin{aligned} & 1.000 \\
-0.082 & \end{aligned}$ & 1.000 & & & & & & & & & & & \\
\hline Caro & $-0.312^{* * *}$ & $-0.216^{*}$ & $-0.195 \mathrm{~ns}$ & $-0.143 \mathrm{~ns}$ & $-0.178^{* *}$ & $-0.063 \mathrm{~ns}$ & $-0.402^{* * *}$ & $0.936 * * * *$ & $0.065 \mathrm{~ns}$ & 1.000 & & & & & & & & & & \\
\hline Flav & $-0.588 * *$ & $-0.319^{* * *}$ & $-0.588 * * *$ & $-0.407 * * *$ & -0.350 *** & $-0.417^{* * *}$ & $-0.519 * * *$ & $0.274^{* *}$ & $-0.463 * *$ & $0.283^{*}$ & 1.000 & & & & & & & & & \\
\hline $\begin{array}{l}\text { TSS } \\
\text { TSP }\end{array}$ & $\begin{array}{l}0.466 * * * \\
0.577 * * *\end{array}$ & $\begin{array}{l}0.369^{* * * *} \\
0.423 * *\end{array}$ & $\begin{array}{l}0.492 * * * * * \\
0.616 * *\end{array}$ & $\begin{array}{l}0.430 * * * * * \\
0.59 * * *\end{array}$ & 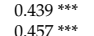 & $\begin{array}{l}0.412 * * * * \\
0.30 * * *\end{array}$ & $0.587 * * * *$ & $-0.304 * * * *$ & $0.526^{* * * *}$ & $-0.310 * * *$ & $-0.648 * * * *$ & $\begin{array}{l}1.000 \\
0.650^{* * * * *}\end{array}$ & & & & & & & & \\
\hline $\begin{array}{l}15 \mathrm{P} \\
\mathrm{H}_{2} \mathrm{O}_{2}\end{array}$ & $\begin{array}{c}0.577 * * * * * * \\
-0.623 * *\end{array}$ & $\begin{array}{c}0.423 * * * * * * \\
-0.548 * * *\end{array}$ & $\begin{array}{c}0.6161^{* * * *} \\
-0.618^{* * *}\end{array}$ & $\begin{array}{c}0.509 * * * * \\
-0.564^{* * *}\end{array}$ & $\begin{array}{c}0.457 * * * * * * \\
-0.556 * *\end{array}$ & $\begin{array}{c}0.300^{* *} \\
-0.441^{* * *}\end{array}$ & $\begin{array}{c}0.783 * * * * \\
-0.799^{* * *}\end{array}$ & $\begin{array}{c}-0.449 * * * * \\
0.485 * * *\end{array}$ & $\begin{array}{c}0.6766^{* * *} \\
-0.675 * *\end{array}$ & $\begin{array}{c}-0.400^{* * *} \\
0.42 * * *\end{array}$ & $\begin{array}{c}-0.5433^{* * *} \\
0.57 * *\end{array}$ & $\begin{array}{c}0.651 * * * * * \\
-0.651^{* * *}\end{array}$ & $\begin{aligned} 1.000 \\
0.011 * * *\end{aligned}$ & & & & & & & \\
\hline $\mathrm{MDA}^{2}$ & -0.480 **** & $-0.463 * * * *$ & -0.573 *** & $\begin{array}{l}-0.564 \\
-0.538 * *\end{array}$ & $\begin{array}{l}-0.056 \\
-0.463 * * * *\end{array}$ & $\begin{array}{l}-0.441 \\
-0.381 * * *\end{array}$ & $\begin{array}{l}-0.199 * * \\
-0.754 * *\end{array}$ & 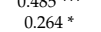 & $\begin{array}{l}-0.675 \text { * } \\
-0.750 * *\end{array}$ & $\begin{array}{l}0.428 \\
0.126 \mathrm{~ns}\end{array}$ & $0.402 * * *$ & $\begin{array}{l}-0.051 \\
-0.474 * * *\end{array}$ & 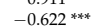 & $\begin{array}{l}1.0000 * \\
0.712^{* * * *}\end{array}$ & 1.000 & & & & & \\
\hline $\begin{array}{l}\text { CAT } \\
\text { APX }\end{array}$ & $\begin{array}{l}-0.671 * * * * * \\
-0.670 * *\end{array}$ & $\begin{array}{l}-0.567 * * * * * \\
-0.544 * *\end{array}$ & $\begin{array}{l}-0.750 * * * * * \\
-0.736 * *\end{array}$ & $\begin{array}{l}-0.6577 * * * 6 \\
-0.635 * *\end{array}$ & $\begin{array}{l}-0.5355_{* * * *}^{*} \\
-0.535 * *\end{array}$ & $\begin{array}{l}-0.443 * * * * * \\
-0.434 * *\end{array}$ & $\begin{array}{l}-0.845 * * * * 7 * \\
-0.784 *\end{array}$ & $\begin{array}{l}0.467 * * * * * * \\
0.500 * *\end{array}$ & $\begin{array}{l}-0.740 * * * * 4 * \\
-0.648 *\end{array}$ & 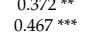 & $\begin{array}{l}0.632 * * * * * \\
0.560 * * *\end{array}$ & $\begin{array}{l}-0.5477 * * * * * \\
-0.570 * *\end{array}$ & $\begin{array}{l}-0.773 * * * * * 2 * \\
-0.827 * *\end{array}$ & 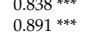 & $\begin{array}{l}0.7454^{* * * *} \\
0.69 *\end{array}$ & $\begin{array}{l}-0.713 * * * * \\
-0748 * *\end{array}$ & $\begin{array}{l}1.000 \\
0.800\end{array}$ & 1000 & & \\
\hline POD & $-0.530 * * *$ & $-0.463^{* * * *}$ & $-0.554 * * *$ & $-0.505 * * *$ & $-0.524 * * *$ & -0.272 ** & $-0.763 * * *$ & $0.466 * * 4$ & $-0.642^{* * *}$ & $0.445 * * *$ & $0.453^{* * *}$ & $-0.585^{* * *}$ & -0.875 *** & $0.883 * x+4$ & $0.633 * * *$ & $-0.831^{* * *}$ & $0.814^{* * * *}$ & $0.896 * * * t$ & 1.000 & \\
\hline SOD & -0.559 *** & $-0.511 * * *$ & $-0.658 * * *$ & $-0.599 * * *$ & -0.459 & $-0.424 * * *$ & $-0.729 * * *$ & $0.383 * * 4$ & $-0.651^{* * * *}$ & $0.279 * *$ & $0.424 * * *$ & $-0.396 * * *$ & $-0.713^{* * *}$ & $0.703 * * *$ & $0.638 * * *$ & $-0.589 * * *$ & $0.740^{* * * *}$ & $0.716 * *$ & $0.657 * *$ & 1.000 \\
\hline
\end{tabular}

ns = non-significant; ${ }^{*}, * *$ and ${ }^{* * *}=$ significant at $0.05,0.01$ and 0.001 levels, respectively. RFW = root fresh weight; SFW = shoot fresh weight; RDW = root dry weight; SDW = shoot dry weight; $\mathrm{RL}=$ root length; $\mathrm{SL}=$ shoot length; Chla = chlorophyll $\mathrm{a} ; \mathrm{Chlb}=$ Chlorophyll $\mathrm{b}$; $\mathrm{TChl}=$ total chlorophyll; Caro = Carotenoids; Flav = flavonoids; TSS = total soluble sugars; $\mathrm{TSP}=$ total soluble proteins; $\mathrm{H}_{2} \mathrm{O}_{2}=$ hydrogen peroxide; $\mathrm{MDA}=$ malonaldehyde; $\mathrm{AsA}=$ ascorbic acid $; \mathrm{CAT}=$ catalase; $\mathrm{APX}=$ ascorbate peroxidase; $\mathrm{POD}=$ peroxidase; SOD = superoxide dismutase. 


\section{Discussion}

In the current study, twelve different Bacillus spp. strains were isolated from textile effluent of Kamal textile, Faisalabad, Punjab, Pakistan. The selection criteria of Bacillus species out of 12 isolates were superior in drought tolerance and better plant PGP characteristics. Comparative analysis based on the bacterial $16 \mathrm{~S}$ rRNA gene sequence has arisen as a preferable molecular technique for the identification [43]. The gene sequences of the smallest subunit (16S) were commonly used to study the phylogenetic relationships, but, later, it has been extensively used as a molecular marker for the identification of an unknown bacterium to the genus and species level [44]. In the present study, 16S rRNA nucleotides sequences of bacterial isolate strain (accession number) BEB1 (MW350048), BEB2 (MW350049) showed 96.58 and 97.99 percent identity with Bacillus cereus, respectively. The 16S rRNA sequence of isolated strain BEB3 (MW350050) showed a 98.61 percent identity with Bacillus tropicus keeping 100\% query coverage. Isolated strain BEB4 (MW350051) showed a 98.20 percent identity with Bacillus thuringiensis. Kadam [45] also revealed the presence of indigenous bacillus microflora in textile wastewaters. The previous studies on the tannery wastewater confirmed the presence and isolation of B. tropicus and B. thuringiensis species $[46,47]$. Bacteria isolated from different textile effluents were closely related to genera bacillus recently also identified from the hospital, domestic and industrial wastewater samples [48,49]. Studies by [45] also revealed the presence of bacillus microflora in textile wastewaters. These observations corroborate with a previous study which reported the isolation of Bacillus, Pseudomonas, Serattia and other bacterial species from textile dye effluent [50].

Selected PGPR strains were also subjected to characterize their potential for in-vitro plant growth promoting traits including nitrogen fixation, ammonia production, IAA synthesis and phosphate solubilization (Table 1). The appearance of a blue halo zone diameter on nitrogen free malate medium was observed as a qualitative indication of atmospheric nitrogen fixation and results correlate with previous studies [51,52]. In a previous study, the bacillus strain FSS2C was reported as an ammonia producing bacteria [27]. In another study, the plant growth promoting bacillus species were described as positive for the production of ammonia [53]. The production of IAA is highly promoted by tryptophan as a substrate for many bacterial species; such bacterial strains follow the biochemical pathway of IAA synthesis dependent upon tryptophan as a source substrate [3]. Our results are analogous to the previously isolated bacterial strains from the soil and wastewater that were only able to produce IAA when supplemented with substrate [31]. The decrease in IAA production under stress might be due to the low bacterial growth by osmotic pressure caused by the PEG [54]. Many of the bacterial strains previously isolated from the water and wastewater are also plant beneficial and able to solubilize inorganic phosphate for the plants $[2,3]$. Results are also in correlation with previous findings on the phosphate solubilization by bacterial species [31]. Strain BEB1 grows well and shows a maximum tolerance to the drought stress even at the lowest water potential. The growth of tested strains (OD $600 \mathrm{~nm}$ ) on varying water potential by PEG concentration is also shown (Figure 2). Our findings were demonstrated with previously isolated bacteria from semi-arid conditions [32]. The growth of bacterial strains decreases as the concentration of the PEG increases in the LB broth medium, and the concentration of PEG tolerated by a bacterial strain is marked as the tolerance level of that isolate [54].

Overall plant growth and yield reduction in numerous cereal crops have been reported due to the water deficient condition [7]. Drought stress was lessened in maize plants that were inoculated with Bacillus spp. strains in this study. There were increases in nutrient uptake and plant height, as well as root and leaf biomass for the inoculated plants under drought stress. All these effects have been related to PGPB's ability to reduce drought stress in maize [55]. Many bacillus bacterial strains have been reported as efficient PGPR in recent years [56]. In the present investigation, the water deficit (5-8\% water in soil) significantly $(p \leq 0.001)$ lowered the shoot and root fresh and dry weight of maize cultivars (V1: FH-1046; V2: YH-5427). The reduction in plant growth and biomass might be due to increased levels 
of lipid peroxidation, $\mathrm{H}_{2} \mathrm{O}_{2}$ and disruption in nutrient contents of non-inoculated maize seedlings. Drought stress is well known for dramatically reducing photosynthetic pigments, associated with decreased plant growth and yield [57]. Furthermore, IAA production by PGPB increases plant growth, root elongation and development to substantially improve nutrient and water acquisition [58]. In the present study, increased plant biomasses were envisioned owing to contribution of nitrogen fixation, ammonia production IAA synthesis and phosphate-solubilization capability of bacillus species as had been earlier reported in drought stressed maize grown with application of dry-Caribbean Bacillus spp. strains [59].

Drought stress also reduces the synthesis of green pigments (chlorophyll contents), resulting in a slower rate of photosynthesis [60]. Chlorophyll $a, b$ and total chlorophyll content decreased significantly in both maize cultivars examined in this study. Higher photosynthetic pigments of drought stressed maize plants under bacillus species inoculation probably results from the activation of enzymatic pathways for chlorophyll biosynthesis, limits in ROS production or increased solubilization and bioavailability of organic minerals i.e., $\mathrm{Mg}$ [3]. Increased chlorophyll contents are likely to boost the plant's photosynthetic activity as obvious from higher fresh and dry weights of inoculated maize plants, particularly the bacterial inoculation. Our results coincide with the findings that Bacillus strain application boosted the growth and chlorophyll content of maize due to an increase in chlorophyll biosynthesis and nutrient balance [59]. An interesting observation was that PGPB influenced the biomass and chlorophyll contents not only when maize plants were exposed to drought, which was consistent with our hypothesis.

In the absence of bacillus species strains, drought stress significantly increased in plants $\mathrm{H}_{2} \mathrm{O}_{2}$ levels with concomitant rise in lipid peroxidation and relative membrane permeability in both maize cultivars (Figure 4). Under water-stress conditions, high lipid peroxidation occurs because of elevated levels of ROS damaging plant ultra-structures [61]. In the current study, maize plants subjected to water deficit conditions accumulated a high amount of $\mathrm{H}_{2} \mathrm{O}_{2}$ and MDA. However, exogenous PGPR strains are said to significantly reduce $\mathrm{H}_{2} \mathrm{O}_{2}$ and MDA levels [3]. Under abiotic stress, such as drought, $\mathrm{H}_{2} \mathrm{O}_{2}$ is believed to be produced due to high oxidative stress [62]. Both water-stressed and non-stressed maize cultivars benefited from bio seed primed bacterial treatments, which significantly increased the ascorbic acid content. An increase in ascorbic acid level has a significant impact on plant fresh and dry biomass of both maize cultivars grown under water-limited conditions, as can be inferred from the data. An increase in ascorbic acid was observed in different crops, such as wheat [63], tomato [64], and canola [65], which are becoming more resistant to water stress.

Antioxidant enzymes are indicators of plant defense against stress, which scavenge ROS under drought stressed conditions. Alterations in plant protein contents upon drought exposure might be owing to protein degradation or enhanced antioxidative activities which disrupt the plant growth [31]. Antioxidant enzymes such as catalase (CAT), peroxidase (POD), ascorbate peroxidase (APX), and superoxide dismutase (SOD) can protect plants from oxidative stress [66]. Under water stress, the activities of CAT, POD, APX, and SOD enzymes increased in the current study (Figure 4). Under both water regimes, various applied bacterial PGPR strains resulted in deceased activity of CAT, POD, APX, and SOD in both cultivars. Inoculation with bacillus specie strains significantly decrease in ROS generation and lipid peroxidation contents as well as the activities of CAT, POD, APX and SOD in both of the cultivars. These findings corroborate previous reports of increased antioxidant enzyme activity under stress in maize treated with bacteria [31]. The fact that both the cultivars had different responses confirmed that the activities of enzymatic antioxidants could be due to genetic differences between them [2,7]. The correlation between all physiological and biochemical parameters studied and their placement in a component chart by factor analysis resembled previous studies.

The Bacillus genera have proven to be an effective ally in the management of drought and other abiotic stresses in a variety of crops [4,56]. Previous research [59] demonstrated the ability of co-inoculation to alleviate drought stress under non-sterile soil conditions. 
Nonetheless, our findings in maize indicate that these four Bacillus spp. strains individually induce a similar drought stress amelioration effect in plant growth under sterile soil conditions, which is dependent on a specific plant-strain interaction evident in the differences in the evaluated antioxidant responses.

\section{Conclusions}

It was concluded that isolated bacterial strains BEB1-4 are capable of tolerating drought stress levels though efficient nitrogen fixation, phosphate solubilization, ammonia and IAA production. Our results confirmed that drought stress inhibited plant biomass and nutrient contents in maize cultivars in a cultivar specific manner. Application of bacterial species confers more advantageous growth as reflected from higher root (36.73\%) and shoot $(56.12 \%)$ biomasses, photosynthetic pigments $(32.76 \%)$, biochemical attributes while maintaining lower levels of lipid peroxidation $(59.14 \%)$, and antioxidants. It was concluded that these bacillus species may be used as bio-inoculant and bioremediation tools synergistically with crop plants in water deficit environments for sustainable food production. To determine the use of these PGPR candidates as microbial agents under drought stress, corresponding assays may be necessary to evaluate the performance of the four selected isolates in field conditions.

Author Contributions: Conceptualization, M.Z.H. and S.J.; methodology, M.Z.H. and S.J.; software, M.Z.H. and M.A.; validation, M.Z.H., S.J. and M.A.; formal analysis, M.A.; investigation, M.A.; resources, S.J., M.Z.H., M.H.S. and A.A.; data curation, M.A.; writing-original draft preparation, M.A.; writing-review and editing, S.J. and M.A.; visualization, M.A.; supervision, S.J.; project administration, S.J. and M.Z.H.; funding acquisition, M.H.S. and A.A. All authors have read and agreed to the published version of the manuscript.

Funding: A part of this research was funded by National Research Program for Universities (NRPU), Higher Education Commission, Islamabad (grant number 5567/Punjab/NRPU/R\&D/HEC/2016).

Institutional Review Board Statement: Not applicable.

Informed Consent Statement: Not applicable.

Data Availability Statement: The dataset generated during and/or analyzed during the current study are available from the corresponding author on reasonable request.

Acknowledgments: The authors are thankful to the Ayub Agricultural Research Institute, Faisalabad, Pakistan for providing the seeds of maize varieties. The authors would like to express their deepest gratitude to the University of Tabuk for the technical support for this study.

Conflicts of Interest: The authors declare no conflict of interest.

\section{References}

1. Naveed, M.; Mitter, B.; Reichenauer, T.G.; Wieczorek, K.; Sessitsch, A. Increased drought stress resilience of maize through endophytic colonization by Burkholderia phytofirmans PsJN and Enterobacter sp. FD17. Environ. Exp. Bot. 2014, 97, 30-39. [CrossRef]

2. Ullah, A.; Akbar, A.; Luo, Q.; Khan, A.H.; Manghwar, H.; Shaban, M.; Yang, X. Microbiome diversity in cotton rhizosphere under normal and drought conditions. Microb. Ecol. 2019, 77, 429-439. [CrossRef] [PubMed]

3. Khan, Z.; Rho, H.; Firrincieli, A.; Hung, S.H.; Luna, V.; Masciarelli, O.; Kim, S.-H.; Doty, S.L. Growth enhancement and drought tolerance of hybrid poplar upon inoculation with endophyte consortia. Curr. Plant Biol. 2016, 6, 38-47. [CrossRef]

4. Ali, L.; Khalid, M.; Asghar, H.N.; Asgher, M. Scrutinizing of rhizobacterial isolates for improving drought resilience in maize (Zea mays). Int. J. Agric. Biol. 2017, 19, 1054-1064. [CrossRef]

5. Daffonchio, D.; Hirt, H.; Berg, G. Plant-microbe interactions and water management in arid and saline soils. In Principles of Plant-Microbe Interactions: Microbes for Sustainable Agriculture; Springer: Cham, Switzerland, 2015; pp. 265-276. [CrossRef]

6. Gepstein, S.; Glick, B.R. Strategies to ameliorate abiotic stress-induced plant senescence. Plant Mol. Biol. 2013, 82, 623-633. [CrossRef] [PubMed]

7. Moreno-Galván, A.; Romero-Perdomo, F.A.; Estrada-Bonilla, G.; Meneses, C.H.S.G.; Bonilla, R.R.J.M. Dry-caribbean Bacillus spp. strains ameliorate drought stress in maize by a strain-specific antioxidant response modulation. Microorganism 2020, 8, 823. [CrossRef] 
8. Allah, E.F.; Alqarawi, A.A. Alleviation of adverse impact of salt in Phaseolus vulgaris L. by arbuscular mycorrhizal fungi. Pak. J. Bot. 2015, 47, 1167-1176.

9. Agami, R.A.; Medani, R.A.; Abd El-Mola, I.A.; Taha, R.S. Exogenous application with plant growth promoting rhizobacteria (PGPR) or proline induces stress tolerance in basil plants (Ocimum basilicum L.) exposed to water stress. Int. J. Environ. Agric. Res. 2016, 2, 78.

10. Ullah, A.; Sun, H.; Yang, X.; Zhang, X. Drought coping strategies in cotton: Increased crop per drop. Plant Biotechnol. J. 2017, 15, 271-284. [CrossRef]

11. Zulfiqar, U.; Ishfaq, M.; Yasin, M.U.; Ali, N.; Ahmad, M.; Ullah, A.; Hameed, W. Performance of maize yield and quality under different irrigation regimes and nitrogen levels. J. Glob. Innov. Agric. Sci. 2017, 5, 159-164.

12. Shams, S.; Sahu, J.; Rahman, S.S.; Ahsan, A.J. Sustainable waste management policy in Bangladesh for reduction of greenhouse gases. Sustain. Cities Soc. 2017, 33, 18-26. [CrossRef]

13. Glick, B.R. Bacteria with ACC deaminase can promote plant growth and help to feed the world. Microbiol. Res. 2014, 169, 30-39. [CrossRef] [PubMed]

14. Sandhya, V.; Shrivastava, M.; Ali, S.Z.; Prasad, V.S.S.K.J. Endophytes from maize with plant growth promotion and biocontrol activity under drought stress. Russ. Agric. Sci. 2017, 43, 22-34. [CrossRef]

15. Shahzad, R.; Khan, A.L.; Bilal, S.; Waqas, M.; Kang, S.-M.; Lee, I.-J. Inoculation of abscisic acid-producing endophytic bacteria enhances salinity stress tolerance in Oryza sativa. Environ. Exp. Bot. 2017, 136, 68-77. [CrossRef]

16. Rashid, M.I.; Mujawar, L.H.; Shahzad, T.; Almeelbi, T.; Ismail, I.M.I.; Oves, M. Bacteria and fungi can contribute to nutrients bioavailability and aggregate formation in degraded soils. Microbiol. Res. 2016, 183, 26-41. [CrossRef] [PubMed]

17. Adesemoye, A.O.; Yuen, G.; Watts, D.B. Microbial inoculants for optimized plant nutrient use in integrated pest and input management systems. In Probiotics and Plant Health; Springer: Singapore, 2017; pp. 21-40.

18. Prescott, H. Laboratory Exercises in Microbiology, 5th ed.; John Wiley \& Sons: Hoboken, NJ, USA, 2002.

19. Barrow, G.I.; Feltham, R.K.A. Manual for the Identification of Medical Bacteria, Cowan and Steels; Cambridge University Press: Cambridge, UK, 1993; Volume 1, p. 331.

20. Seibold, G.; Auchter, M.; Berens, S.; Kalinowski, J.; Eikmanns, B.J. Utilization of soluble starch by a recombinant Corynebacterium glutamicum strain: Growth and lysine production. J. Biotechnol. 2006, 124, 381-391. [CrossRef]

21. Vijayaraghavan, P.; Vincent, S.G.P. A simple method for the detection of protease activity on agar plates using bromocresolgreen dye. J. Biochem. Technol. 2013, 4, 628-630.

22. Paulo, E.M.; Vasconcelos, M.P.; Oliveira, I.S.; Affe, H.M.d.J.; Nascimento, R.; Melo, I.S.d.; Roque, M.R.d.A.; Assis, S.A.d. An alternative method for screening lactic acid bacteria for the production of exopolysaccharides with rapid confirmation. Food Sci. Technol. 2012, 32, 710-714. [CrossRef]

23. Weisburg, W.G.; Barns, S.M.; Pelletier, D.A.; Lane, D.J. $16 \mathrm{~S}$ ribosomal DNA amplification for phylogenetic study. J. Bacteriol. 1991, 173, 697-703. [CrossRef]

24. Saitou, N.; Nei, M. The neighbor-joining method: A new method for reconstructing phylogenetic trees. Mol. Biol. Evol. 1987, 4, 406-425. [CrossRef]

25. Kumar, S.; Stecher, G.; Li, M.; Knyaz, C.; Tamura, K. MEGA X: Molecular evolutionary genetics analysis across computing platforms. Mol. Biol. Evol. 2018, 35, 1547-1549. [CrossRef] [PubMed]

26. Felsenstein, J. Confidence limits on phylogenies: An approach using the bootstrap. Evolution 1985, 39, 783-791. [CrossRef] [PubMed]

27. Mahmood, F.; Shahid, M.; Hussain, S.; Haider, M.Z.; Shahzad, T.; Ahmed, T.; Noman, M.; Rasheed, F.; Khan, M.B. Bacillus firmus strain FSS2C ameliorated oxidative stress in wheat plants induced by azo dye (reactive black-5). 3 Biotech 2020, 10, 40. [CrossRef]

28. Penrose, D.M.; Glick, B.R. Methods for isolating and characterizing ACC deaminase-containing plant growth-promoting rhizobacteria. Physiol. Plant 2003, 118, 10-15. [CrossRef]

29. Bilal, R.; Rasul, G.; Qureshi, J.A.; Malik, K.A. Characterization of Azospirillum and related diazotrophs associated with roots of plants growing in saline soils. World J. Microbiol. Biotechnol. 1990, 6, 46-52. [CrossRef]

30. Nautiyal, C.S. An efficient microbiological growth medium for screening phosphate solubilizing microorganisms. FEMS Microbiol. Lett. 1999, 170, 265-270. [CrossRef]

31. Abbas, S.; Javed, M.T.; Shahid, M.; Hussain, I.; Haider, M.Z.; Chaudhary, H.J.; Tanwir, K.; Maqsood, A. Acinetobacter sp. SG-5 inoculation alleviates cadmium toxicity in differentially $\mathrm{Cd}$ tolerant maize cultivars as deciphered by improved physiobiochemical attributes, antioxidants and nutrient physiology. Plant. Physiol. Biochem. 2020, 155, 815-827. [CrossRef] [PubMed]

32. Rashid, U.; Yasmin, H.; Hassan, M.N.; Naz, R.; Nosheen, A.; Sajjad, M.; Ilyas, N.; Keyani, R.; Jabeen, Z.; Mumtaz, S. Droughttolerant Bacillus megaterium isolated from semi-arid conditions induces systemic tolerance of wheat under drought conditions. Plant Cell Rep. 2021. (Online ahead of print). [CrossRef]

33. Arnon, D.I. Copper enzymes in isolated chloroplasts. Polyphenoloxidase in Beta vulgaris. Plant. Physiol. 1949, 24, 1-15. [CrossRef]

34. Zhishen, J.; Mengcheng, T.; Jianming, W. The determination of flavonoid contents in mulberry and their scavenging effects on superoxide radicals. Food Chem. 1999, 64, 555-559. [CrossRef]

35. Irigoyen, J.; Einerich, D.; Sánchez-Díaz, M. Water stress induced changes in concentrations of proline and total soluble sugars in nodulated alfalfa (Medicago sativd) plants. Physiol. Plant. 1992, 84, 55-60. [CrossRef] 
36. Bradford, M.M. A rapid and sensitive method for the quantitation of microgram quantities of protein utilizing the principle of protein-dye binding. Anal. Biochem. 1976, 72, 248-254. [CrossRef]

37. Mukherjee, S.; Choudhuri, M. Implications of water stress-induced changes in the levels of endogenous ascorbic acid and hydrogen peroxide in Vigna seedlings. Physiol. Plant. 1983, 58, 166-170. [CrossRef]

38. Velikova, V.; Yordanov, I.; Edreva, A. Oxidative stress and some antioxidant systems in acid rain-treated bean plants: Protective role of exogenous polyamines. Plant Sci. 2000, 151, 59-66. [CrossRef]

39. Cakmak, I.; Horst, W.J. Effect of aluminium on lipid peroxidation, superoxide dismutase, catalase, and peroxidase activities in root tips of soybean (Glycine max). Physiol. Plant. 1991, 83, 463-468. [CrossRef]

40. Chance, B.; Maehly, A. Assay of catalases and peroxidases. In Methods in Enzymology; Colowick, S.P., Kaplan, N.O., Eds.; Academic Press: Cambridge, MA, USA, 1955.

41. Zhang, J.; Kirkham, M.B. Drought-stress-induced changes in activities of superoxide dismutase, catalase, and peroxidase in wheat species. Plant Cell Physiol. 1994, 35, 785-791. [CrossRef]

42. Giannopolitis, C.N.; Ries, S.K. Superoxide dismutases: II. Purification and quantitative relationship with water-soluble protein in seedlings. Plant. Physiol. 1977, 59, 315-318. [CrossRef]

43. Fuks, G.; Elgart, M.; Amir, A.; Zeisel, A.; Turnbaugh, P.J.; Soen, Y.; Shental, N.J.M. Combining 16S rRNA gene variable regions enables high-resolution microbial community profiling. Microbiome 2018, 6, 17. [CrossRef]

44. Kai, S.; Matsuo, Y.; Nakagawa, S.; Kryukov, K.; Matsukawa, S.; Tanaka, H.; Iwai, T.; Imanishi, T.; Hirota, K.J. Rapid bacterial identification by direct PCR amplification of $16 \mathrm{~S}$ rRNA genes using the MinION ${ }^{\mathrm{TM}}$ nanopore sequencer. FEBS Open Bio 2019, 9 , 548-557. [CrossRef]

45. Kadam, A.A.; Kamatkar, J.D.; Khandare, R.V.; Jadhav, J.P.; Govindwar, S.P. Solid-state fermentation: Tool for bioremediation of adsorbed textile dyestuff on distillery industry waste-yeast biomass using isolated Bacillus cereus strain EBT1. Environ. Sci. Pollut. Res. 2013, 20, 1009-1020. [CrossRef]

46. Mohanty, S.; Bose, S.; Jain, K.G.; Bhargava, B.; Airan, B. TGF $\beta 1$ contributes to cardiomyogenic-like differentiation of human bone marrow mesenchymal stem cells. Int. J. Cardiol. 2013, 163, 93-99. [CrossRef] [PubMed]

47. Samanta, S.; Datta, D.; Halder, G. Biodegradation efficacy of soil inherent novel sp. Bacillus tropicus (MK318648) onto low density polyethylene matrix. J. Polym. Res. 2020, 27, 324. [CrossRef]

48. Chowdhary, P.; More, N.; Raj, A.; Bharagava, R.N. Characterization and identification of bacterial pathogens from treated tannery wastewater. Microbiol. Res. Int. 2017, 5, 30-36. [CrossRef]

49. Greay, T.L.; Gofton, A.W.; Zahedi, A.; Paparini, A.; Linge, K.L.; Joll, C.A.; Ryan, U.M. Evaluation of 16 S next-generation sequencing of hypervariable region 4 in wastewater samples: An unsuitable approach for bacterial enteric pathogen identification. Sci. Total Environ. 2019, 670, 1111-1124. [CrossRef]

50. Jayaseelan, T.; Damodaran, R.; Ganesan, S.; Mani, P. Biochemical characterization and 16s rRNA sequencing of different bacteria from textile dye effluents. J. Drug Deliv. Ther. 2019, 8, 35-40. [CrossRef]

51. Li, X.; Geng, X.; Xie, R.; Fu, L.; Jiang, J.; Gao, L.; Sun, J. The endophytic bacteria isolated from elephant grass (Pennisetum purpureum Schumach) promote plant growth and enhance salt tolerance of Hybrid Pennisetum. Biotechnol. Biofuels 2016, 9, 190. [CrossRef]

52. Wen, P.; Han, Y.; Wu, Z.; He, Y.; Ye, B.-C.; Wang, J. Rapid synthesis of a corncob-based semi-interpenetrating polymer network slow-release nitrogen fertilizer by microwave irradiation to control water and nutrient losses. Arab. J. Chem. 2017, 10, 922-934. [CrossRef]

53. Karthika, S.; Midhun, S.J.; Jisha, M. A potential antifungal and growth-promoting bacterium Bacillus sp. KTMA4 from tomato rhizosphere. Microb. Pathog. 2020, 142, 104049. [CrossRef] [PubMed]

54. Kumar, A.S.; Sridar, R.; Uthandi, S. Mitigation of drought in rice by a phyllosphere bacterium Bacillus altitudinis FD48. Afr. J. Microbiol. Res. 2017, 11, 1614-1625.

55. Shirinbayan, S.; Khosravi, H.; Malakouti, M.J. Alleviation of drought stress in maize (Zea mays) by inoculation with Azotobacter strains isolated from semi-arid regions. Appl. Soil Ecol. 2019, 133, 138-145. [CrossRef]

56. AbdAllah, E.F.; Alqarawi, A.A.; Hashem, A.; Radhakrishnan, R.; Al-Huqail, A.A.; Al-Otibi, F.O.N.; Malik, J.A.; Alharbi, R.I.; Egamberdieva, D. Endophytic bacterium Bacillus subtilis (BERA 71) improves salt tolerance in chickpea plants by regulating the plant defense mechanisms. J. Plant Interact. 2018, 13, 37-44. [CrossRef]

57. Ashraf, M.; Harris, P.J. Photosynthesis under stressful environments: An overview. Photosynthetica 2013, 51, 163-190. [CrossRef]

58. Kamaruzzaman, M.; Abdullah, S.; Hasan, H.A.; Hassan, M.; Othman, A.; Idris, M. Characterisation of Pb-resistant plant growth-promoting rhizobacteria (PGPR) from Scirpus grossus. Biocatal. Agric. Biotechnol. 2020, 23, 101456. [CrossRef]

59. Moreno-Galván, A.E.; Cortés-Patiño, S.; Romero-Perdomo, F.; Uribe-Vélez, D.; Bashan, Y.; Bonilla, R.R. Proline accumulation and glutathione reductase activity induced by drought-tolerant rhizobacteria as potential mechanisms to alleviate drought stress in Guinea grass. Appl. Soil Ecol. 2020, 147, 103367. [CrossRef]

60. Mibei, E.K.; Ambuko, J.; Giovannoni, J.J.; Onyango, A.N.; Owino, W.O. Carotenoid profiling of the leaves of selected African eggplant accessions subjected to drought stress. Food Sci. Nutr. 2017, 5, 113-122. [CrossRef] [PubMed]

61. Lum, M.; Hanafi, M.; Rafii, Y.; Akmar, A. Effect of drought stress on growth, proline and antioxidant enzyme activities of upland rice. J. Anim. Plant Sci. 2014, 24, 1487-1493. 
62. Alam, M.M.; Nahar, K.; Hasanuzzaman, M.; Fujita, M. Exogenous jasmonic acid modulates the physiology, antioxidant defense and glyoxalase systems in imparting drought stress tolerance in different Brassica species. Plant Biotechnol. Rep. 2014, 8, $279-293$. [CrossRef]

63. Smirnoff, N. Ascorbic acid metabolism and functions: A comparison of plants and mammals. Free Radic. Biol. Med. 2018, 122, 116-129. [CrossRef]

64. Amirjani, M.R.; Mahdiyeh, M. Antioxidative and biochemical responses of wheat to drought stress. J. Agric. Biol. Sci. 2013, 8, 291-301.

65. Shafiq, S.; Akram, N.A.; Ashraf, M.; Arshad, A. Synergistic effects of drought and ascorbic acid on growth, mineral nutrients and oxidative defense system in canola (Brassica napus L.) plants. Acta Physiol. Plant. 2014, 36, 1539-1553. [CrossRef]

66. Ghorbanli, M.; Gafarabad, M.; Amirkian, T.; Allahverdi, M.B. Investigation of proline, total protein, chlorophyll, ascorbate and dehydroascorbate changes under drought stress in Akria and Mobil tomato cultivars. Iran. J. Plant. Physiol. 2013, 3, 651-658. 